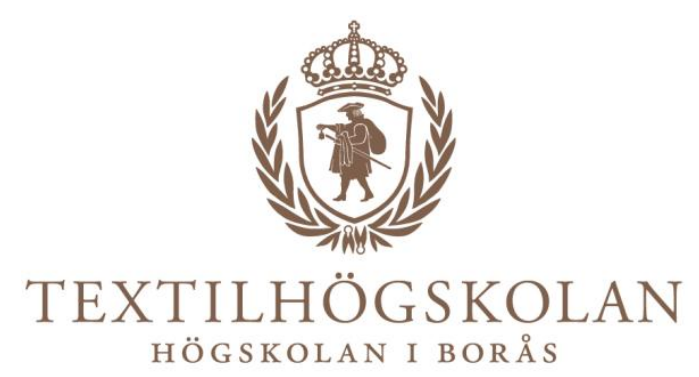

HÖGSKOLAN I BORÅS

\title{
Sustainability in Fashion industry
}

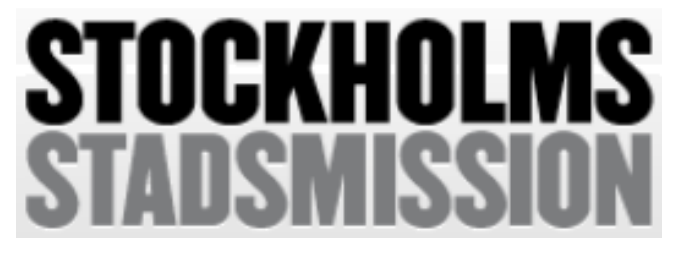

Applied Textile Management

\author{
Michiko Tanaka
}

May $26^{\text {th }} 2010$ 


\section{Abstract}

In recent years Fair Trade's People Tree has succeeded within the fashion industry by making ecological and ethical products fashionable, and subsequently fostering concern about ecological and ethical issues among consumers (1). H\&M has reported peak profits in 2009, even though there was the recession in 2009. At the same time "Fashion for everyone" is the motto of the fashion industry. Global citizens especially citizens in advanced countries know they cannot keep consuming like we do now. As a result, there are two choices in our future when we buy clothes: we can buy ecological products to reduce the ecological foot print, -or we can reuse what we have now.

In this thesis I take a close look at reuse of second-hand remade products. Nowadays you can get modern, up-to-date fashion for a cheaper price. Fashion is always changing - and commercial stores have to make profit to survive by continuing to sell new garments. This raised some questions. One question I had was what the company does with its unsold garments. Another, was what do people do with the garments they don't wear. On the first topic, l've heard some companies donate unsold garments and fabrics to second-hand stores. On the second topic, I think most people either donate their garments to second-hand stores, or thrown them in the garbage. Those who donate their old clothes give them a second life. If the people, who buy many new garments, instead buy or use second-hand or remade garments, we can expect a big consuming change in our society. However, in order to make this happen, need to get people's attention. I've run some experimental projects in a second-hand store in Stockholm to increase awareness of ecological fashion, and try to clear out the old image of buying second-hand as out of date fashion. My hope was to bring more people into the activity and make our global future better.

\footnotetext{
${ }^{1}$ http://www.globalexchange.org/campaigns/sweatshops/3919.html
} 


\section{Table of Contents}

\section{ABSTRACT}

TABLE OF CONTENTS

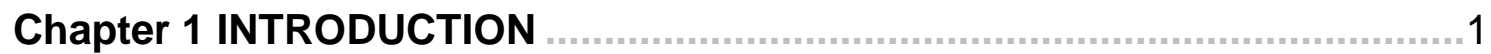

1.1 Background $\ldots$

1.1.1 Fashion market in Sweden .......................................................... 1

1.1.2 Sustainable situation in Fashion industry in Sweden ..................... 1

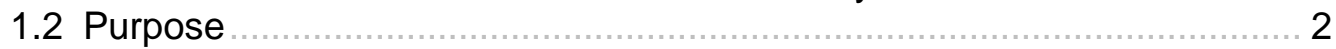

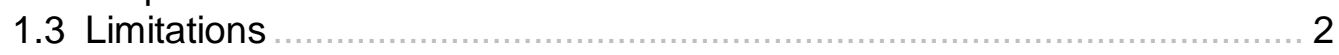

Chapter 2 METHODS

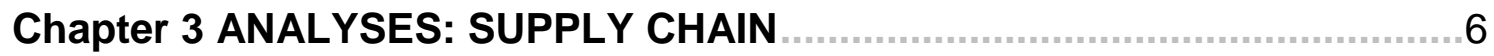

3.1 How to get donation $\ldots$

3.2 Flows in the ware house $\ldots \ldots \ldots \ldots \ldots$

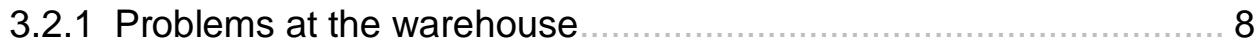

Chapter 4 ANALYSES: BUSINESS STRATEGY

4.1 Stores concepts / layout ……..............................................

4.1.1 Problems in stores …..................................................... 13

4.2 Remake $\ldots . . . .14$

4.2.1 Problems in the remade section ......................................... 16

Chapter 5 ANALYSES: SALES FIGURE

5.1 Current situation $\ldots . .18$

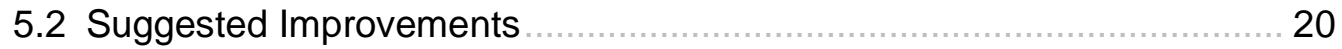

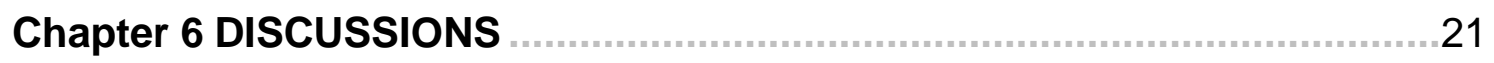

6.1 PROJECT 1: Remade T-shirt collaborate with young designers …......... 24

6.1.1 Project Concept $\ldots \ldots \ldots \ldots \ldots \ldots \ldots . . .24$

6.1.2 Method $\ldots$

6.1.3 Process $\ldots . . . . . . .25$

6.1.4 Result and Analysis

6.1.5 Improvement points 
6.2 PROJECT 2: Collaborate with Fashion designs students of The Swedish School of Textile

6.2.1 Project Concept

6.2.2 Method

6.2.3 Process

35

6.2.4 Result and Analysis

6.2.5 Improvement points

6.3 PROJECT 3: Sell remade products to Japan …................................. 40

6.3.1 Project Concept ................................................................................. 40

6.3.2 Method ........................................................................................ 42

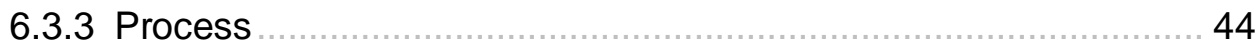

6.3.4 Result and Analysis ............................................................ 47

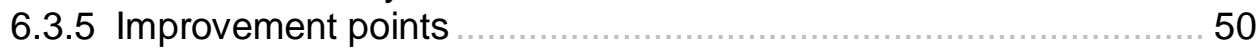

Chapter 7 CONCLUSION 51

Chapter 8 FUTURE PROPOSAL 53

\section{REFERENCES}

\section{APPENDIX 1-6}




\section{INTRODUCTION}

\subsection{Background}

\subsubsection{Fashion market in Sweden}

Swedish people's income is rather high in the world thus they can enjoy fashion. Sweden has successful companies such as H\&M and IKEA, and it's possible get fashion at a reasonable price. $\mathrm{H} \& \mathrm{M}$ has collaborated with haut couture designers, but fashion is not luxury - now it is for everyone, hence the fashion market is more disposal product market. (2)

On the other hand, Sweden has many strong brands such as Filippa K, Acne, and others. Their price range is not as cheap as $\mathrm{H} \& \mathrm{M}$, but they tend to provide more "Stylish life style" to consumers. While Filippa $\mathrm{K}$ is actively engaged in sustainability, Acne is trying to create more fashionable clothes. I've seen several Swedish people who buy Filippa K, Acne and the other expensive brands simultaneously purchasing $\mathrm{H} \& \mathrm{M}$ clothes. It seems there is a good balance between fashion for everyone and high fashion in Sweden.

\subsubsection{Sustainable situation in Fashion industry in Sweden}

When it comes to recycling, Sweden is quit advanced. People in Sweden are paying more attention to ecological fashion - For example, Nudie Jeans has used organic denim, and H\&M has a collection which is made with organic cotton. Filippa $\mathrm{K}$ has a second-hand shop as shop in shop. Second-hand stores in Sweden are very successful as well. The biggest second-hand store in Sweden is Myrorna, and they collect more than 9,000

\footnotetext{
${ }^{2}$ http://www.euromonitor.com/Clothing_And_Footwear_in_Sweden
} 
tons of clothes and textiles per year (3). To use these second-hand garments instead of producing new products, one can significantly reduce their ecological foot-print.

\subsection{Purpose}

Sweden is a leading country for recycling. The purpose of my thesis is to learn the ways they have fostered sustainability in fashion, particularly, through the second-hand economy. I hope to find effective strategies of sustainability for our future.

Second-hand stores in Sweden are mostly run by non-profit organizations, and people donate clothes to the stores when they don't wear them anymore. This system has been established many years ago and has become standard.

As for clothes that companies such as H\&M can't sell, they produce many clothes at a cheaper price. I haven't ever seen these stores empty; they try to fill the garments racks all the time even if consumers aren't buying everything. They hope to keep the store full of garments so as not to lose any chance to sell. I believe, however, there are some garments that will never sell. I started to question where these garments go - If they become garbage, we need to find a solution. Perhaps this solution can combined with second-hand stores.

\subsection{Limitations}

Sustainable fashion should use ecologically friendly, ethically good products and should be locally made. Stockholm's City Mission is an ideal focus for this thesis. City Mission is a well-known non-profit organization in Sweden, and several major Swedish cities have a City Mission branch, such as Gothenburg, Linköping, Kalmar, etc. The activity of these

\footnotetext{
${ }^{3}$ http://www.sweden.se/eng/Home/Society/Sustainability/Facts/Sustainable-livingGoing-back-to-the-future/
} 
organizations is limited to their region; they don't work together across cities. Their activity and contribution are limited to Stockholm, where they remake garments and hire homeless people, vulnerable people and people needing vocational training (e.g. those who haven't worked for 20 years). Thus, City Mission meets one of the sustainability requirements - working locally. Stockholm's City Mission has 8 second-hand stores, and one of them is in the shopping mall. They have collaborated with a designer called "Claesson Koivisto Rune" to make a shopping bag in 2008. Some stores have cafes, or a DJ booth. They're very open for new challenges.

I'm working in the second-hand remade section. They started "remake" in 2007, and are presently planning to expand it. I believe second-hand "remake" has a lot of potential for effective sustainability.

I would next like to explain more about Stcokholm's City Mission. They have homeless shelters (For men, women and young people), whom they help to find work opportunities and re-enter society. They have medical and mental-health doctors, and a school for young people (Picture: 1). Additionally, they patrol central areas of Stockholm at night to pick up or help homeless, youth and adults. They offer summer camps for young and old people and at winter time, volunteers go to houses of elderly people to provide company and to talk with them. They have a church mainly for homeless and they serve a free

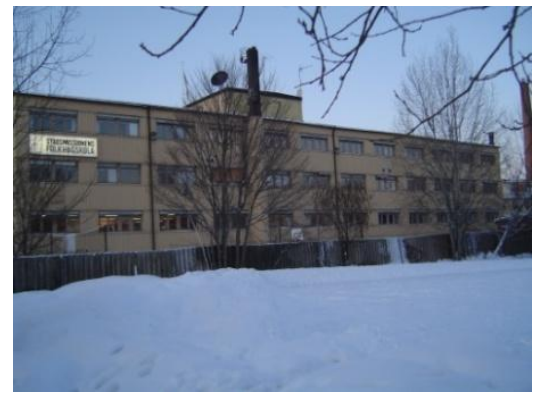

Picture: 1

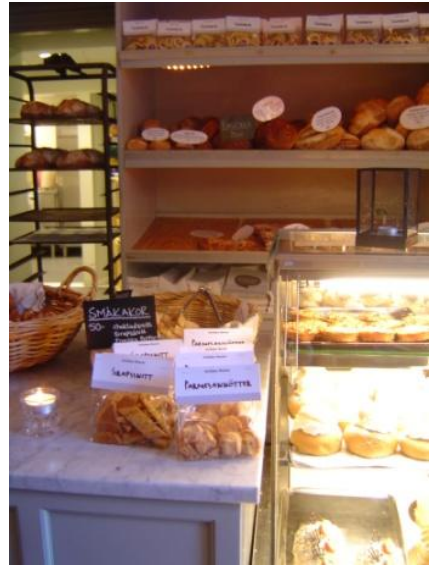

Picture: 2

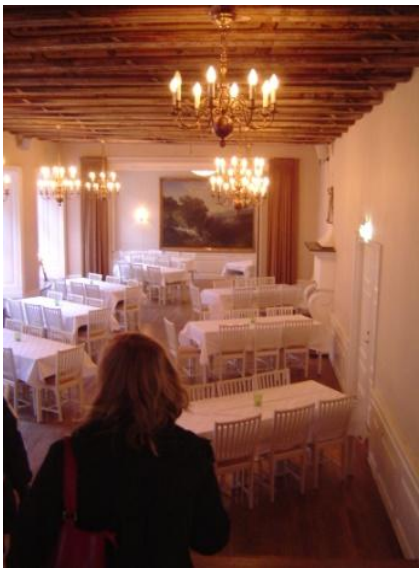

Picture: 3 
Although they have a large number of volunteers already, to help people and contribute to society, they need capital to run the organization.

Stcokholm's City Mission's second-hand store, café (Picture: 2), restaurant, bakery and rental conference room (Picture: 3 ). Are the revenue-generating enterprises which support these activities. They also received donations from well-known companies such as S.E.B, L'ORÉAL, Åhléns and others.

\section{METHODS}

My research involved analyzing Stockholm's City Mission's situation by visiting and working in the warehouse and stores. Through my field study I worked for two months. I could see the problem from the workers' point of view, and, at the same time I administered a questionnaire to the store managers about what they want to improve at the stores. After that, I analyzed the remade section's sales figures divided out by section and year. I initiated some projects to improve the situation they have now and worked to increase the sales in the remade section. Then I created a new project to improve the situation, something that could get people's attention for sustainable fashion, and something that would lead to an increase in sales.

Sofia Minney said in The Design of Prosperity 2006, "Ethical and ecological products don't need to look boring, nor ugly." (4) Thus design plays a big role in sustainability in fashion. One eco-fashion designer, Deborah Lindquist, said "Partnerships and joint ventures are important, as are collaboration of ideas, social media, and networking. I feel that it's the perfect time to team up with someone to create a new idea. We need to

\footnotetext{
${ }^{4} \mathrm{http}: / /$ www.thedesignofprosperity.se/speakers.asp?id=5
} 
help each other and focus on our individual strengths to make our businesses stronger and thereby create a stronger green community." (5) Hence collaboration with designers is a key for sustainable fashion. I will reflect those ideas in to the projects.

Through these projects I expect to see how design can affect sustainability in fashion, and what is the best recycling strategy we can take for our future. Also exposure about the project through media such as magazines and website can be a good method to let people know about sustainable fashion. How to measure the project is affective to sustainable fashion, I will compare remade section's sales figure before we apply the project and after I applied the project to see how it changes. If people start to pay attention to sustainable fashion, they will buy the products which helps to have better sales figure.

${ }^{5}$ http://www.ecouterre.com/9045/16-eco-fashion-predictions-for-2010/ 


\section{ANALYSES: SUPPLY CHAIN}

\subsection{How to get donation}

The main channel to get donations is in the stores is that in their stores. There are three wagons in the store, for clothes and fabrics, dishware and books and CDs. Other channels to get donation is from companies, they donate garments or other products they can't sell under certain conditions, such as Bjorn Borg, they don't want City Mission to resell their products. They want to give the products to homeless people in the shelters. City Mission receives big donations from Åhléns, City Mission can use it for remade clothes and resell. The other way to collect donations has been started since this April; it has started to collect old textiles, garments and dishware from citizens in Solna city (next city to Stockholm). Solna city has started to collect recyclable material from the citizens and they asked for help second-hand stores such as City Mission, Myrorna, Emmaus and etc. these second-hand organizations will collect by rotation.

\subsection{Flows in the ware house}

All donated goods go to Stockholm's City Mission's warehouse in Segeltorp, Stockholm. They receive more than 25 wagons in one day. Furniture or heavy gifts are collected by the drivers. Customers have to reserve collecting cars.

After they sort out the donations into Hardware (Dishes, Paintings, Electronic, Books/CDs) and

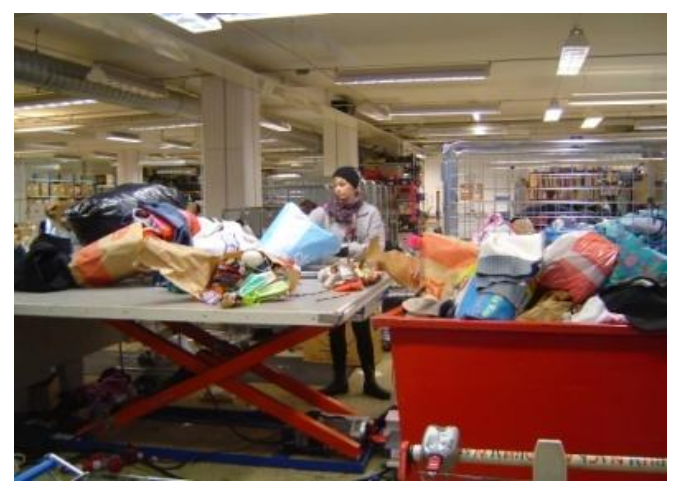
Software (Clothes, shoes and accessories), they sort out into smaller categories (Picture: 4). In the 
hardware section they wash glasses (Picture: 5), polish silver (Picture: 6), antiques are examined for value.

Electronics are checked to determine if it works or not. In the software section, they sort out women / men / children then sort out shirt / skirt / T-shirt / winter jacket etc. In this process they sort out the donations by prices at the same time. The price is on the side of the box (Picture: 7 ).

The Sorting out segment is very important in the supply chain. They collect for the different projects such as jolly project (remade jewelry), T-shirt project (I will explain in "6.1 PEOJECT 1: T-shirt remake collaborate with young designers" P.23). Also they keep special design fabrics for remade garment which suppose to go to garbage due to being worn out or dirty. The next segment is put on price tag / stickers. They have rules to putting the price tags on the garments (Picture: 8). They have the rule in order to make it easier for customers to see the tag. They can print the tag with the computer (Picture: 9). For books, CDs and electronics, each store decide for their own prices.

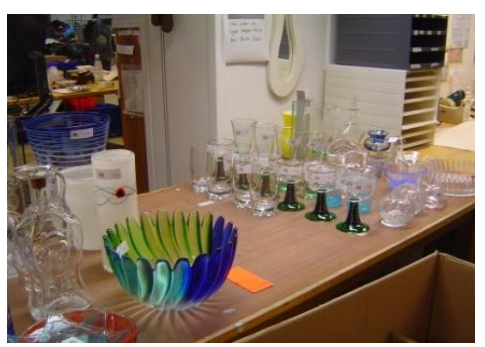

Picture: 5

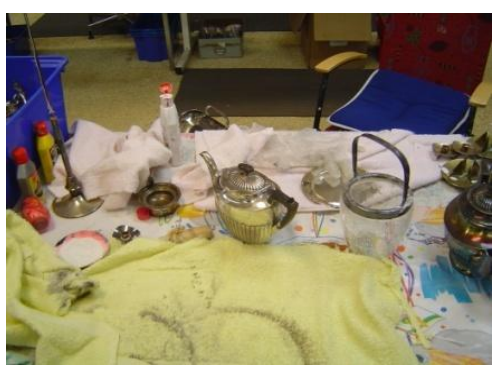

Picture: 6

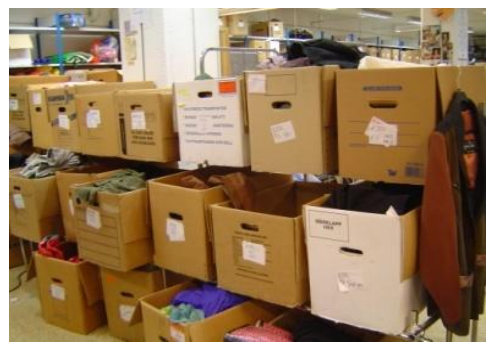

Picture: 7

In the warehouse, they are taking care of other donations that go to shelters owned by Stockholm's City Mission. They have several shelters in Stockholm, for juvenile, woman and man. City Mission receives new products from companies that cannot sell not only garment but also food and cosmetic products. Companies can decide which goods can be resold in the second hand or only donate to shelters. (Picture: $10,11,12)$
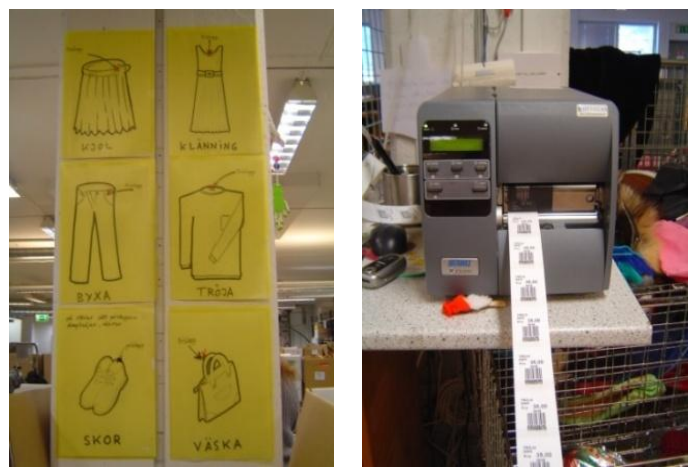

Picture: 8 


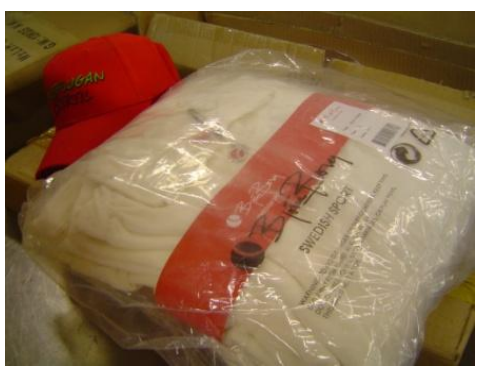

Picture: 10 Björn Borg Sport ware

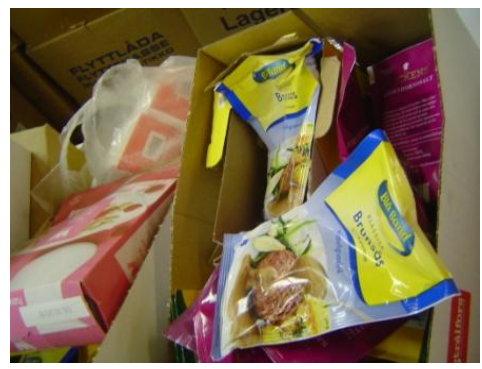

Picture: 11 Donated foods

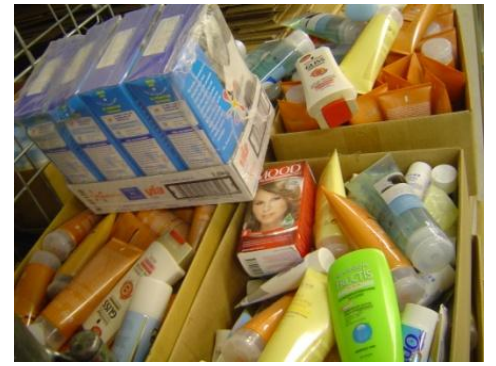

Picture: 12 Donated shampoos and creams

The warehouse is also taking care of store supplies such as toilet paper, soaps, detergents, light balls etc. These are sent to the stores when the warehouse gets requests from stores. City Mission remake furniture as well (Picture: 13). They are remaking furniture in the warehouse. They remade it with materials donated by citizens and companies. In picture 14, these are wall papers and other materials donated from Åhléns.

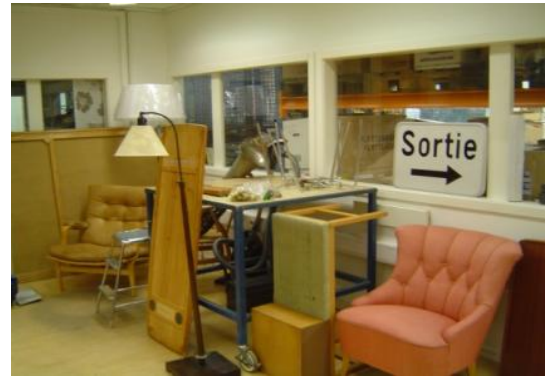

Picture: 13

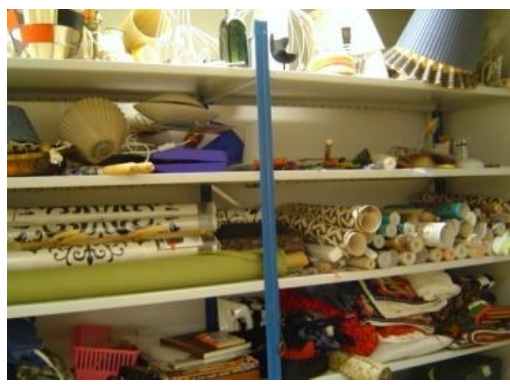

Picture: 14

\subsubsection{Problems at the warehouse}

\section{- The high cost of garbage disposal}

Some donations are worn out or too dirty and cannot be sold in the stores. These gifts end up in the garbage. All garbage is taken care of by a third party. City Mission can sell books and papers to the Recycling Company. City Mission pays to dump clothes they can't sell. The third company sells to the energy production company who use the dump to make energy. City Mission wants to sell clothes to the energy production company directly so that City Mission doesn't need to lose money. Sadly, the energy production company said the amount of garbage is too little for them and they are not willing to sign a contract with City Mission. 
The biggest problem is clothes being dumped; citizens put their donations in front of the doors or in front of the gate of the back side of the store. When it's raining or snowing donations get wet or get dirty. City Mission doesn't wash donation before selling in the stores. These unwilling donations go to garbage as well and City Mission has to pay for disposing them.

City Mission sells books they can't sell as garbage to recycling company. Only $30 \%$ of donation can be sold in the second-hand stores but the other $70 \%$ goes to garbage. They don't make so much money on selling to the recycling company.

The cost for dumping the garbage takes up a lot of the budget at City Mission. They spend 1,000,000kr each year on the garbage. This is the biggest problem for them. If the problem could be solved, they can use the money for helping people more.

\section{- $\quad$ Need more gifts}

Needs more garments for women's underwear, men's wear and dish ware. Women's under wear is expensive to buy and these are highly needed in shelter. City Mission needs Men's wear more for shelter and for secondhand stores. Men's wear donation is one third or less than women's wear. As for dish ware, it is very popular in second-hand stores they want to sell more.

Although they receive a lot of second-hand garments and new garments, they can sell them very well so they don't have stocks. They reduce prices before the season finishes, they think of displays in the store and trying to sell them as quickly as possible. 


\section{ANALYSES: BUSINESS STRATEGY}

\subsection{Stores concepts / layout}

They have eight second-hand stores in Stockholm. They have a good sales strategy to change the concept of the stores by location and the target group. One store is high volume, low price. Other stores are for young people interested in vintage clothes. I've been to every store on my own and helped with them in the stores and I saw even though all stores have own concept and set a specific target group, there are customers of all ages in all of the stores. Dish ware is sold in all of the stores as dish ware is the most popular item in City Mission's second-hand. They display dish ware close to the entrance to get the attention of customers. The biggest store selling CDs is the Hagagatan store, they have a DJ booth, and the DJ plays music in the stores. Gamla Stan store is located in Stortorget. It is an historical area and many tourists visit the store. They are selling antique dishware, furniture and remade products. The assortments fit to the location. Skånegatan store is in the district called "SOHO", known as fashionable district, the store on the street where rowing of young designers and expensive vintage clothes stores. Brand name vintage clothes and accessories are sold in Skånegatan. Lövholmsvägen store is the biggest and oldest store. They are selling cheapest second-hand clothes. They select products to sell depending on the stores' district and target. (Chart: 1)

\begin{tabular}{|c|l|l|c|}
\hline Stores & Specialized Category & Special layout & Picture \\
\hline Hornsgatan & Remade & $\begin{array}{l}\text { Remake Display, } \\
\text { Remake production is } \\
\text { behind the store }\end{array}$ & \\
\hline
\end{tabular}




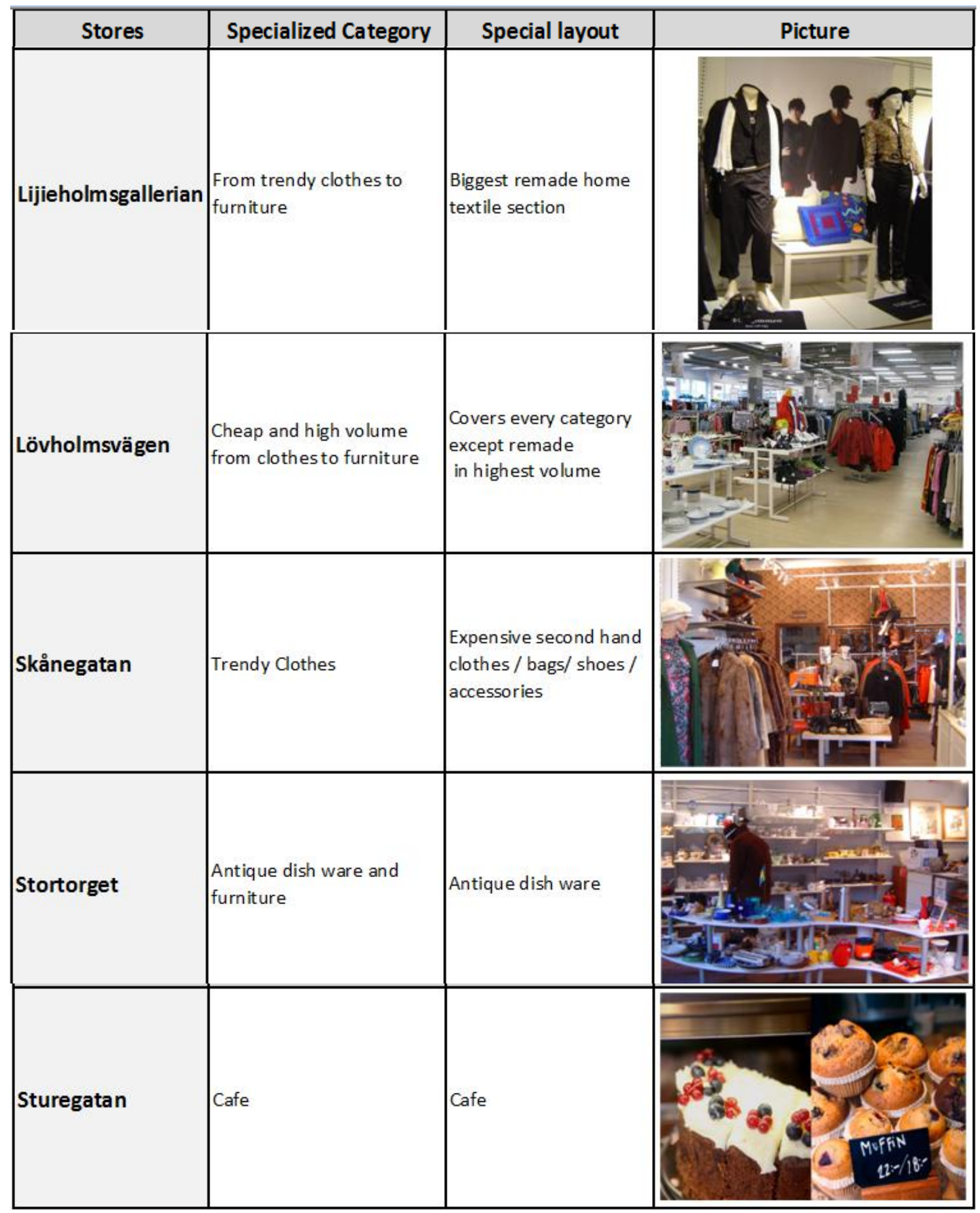




\begin{tabular}{|c|c|c|c|}
\hline Stores & Specialized Category & Special layout & Picture \\
\hline Hagagatan & CD, Record & DJ booth, Cafe & \\
\hline Hantverkargatan & Women's accessory & Expensive accessories & \\
\hline
\end{tabular}

Assortment of stores are different as stores and the price range has diversity as well (Chart: 2,3 ), Most of the donated garments from customers are H\&M and Lindex; low to middle-priced garments. In Skånegatan store is selling brand name clothes especially popular among young people, in Hantverkargatan store they sell famous brand name such as Margaret Howell, Filipa $\mathrm{K}$ and etc.

\begin{tabular}{|c|c|c|c|c|c|c|c|c|c|c|c|}
\hline Shops & Size & Women's & Men's & Kid's & Dishware & Electronic & Books & CD/DVD & Furniture & Remake & Cafe \\
\hline Hagagatan & Middle & $\checkmark$ & $\checkmark$ & $\checkmark$ & $\checkmark$ & $\checkmark$ & $\checkmark$ & $\checkmark$ & $\checkmark$ & & $\checkmark$ \\
\hline Hantverka rgatan & Middle & $\checkmark$ & $\checkmark$ & & $\checkmark$ & & $\checkmark$ & $\checkmark$ & $\checkmark$ & & \\
\hline Hornsgatan & Middle & $\checkmark$ & $\checkmark$ & $\checkmark$ & $\checkmark$ & $\checkmark$ & $\checkmark$ & $\checkmark$ & $\checkmark$ & $\checkmark$ & \\
\hline Liljeholmsgallerian & Middle & $\checkmark$ & $\checkmark$ & $\checkmark$ & $\checkmark$ & $\checkmark$ & $\checkmark$ & $\checkmark$ & $\checkmark$ & $\checkmark$ & \\
\hline Lövholmsvägen & Big & $\checkmark$ & $\checkmark$ & $\checkmark$ & $\checkmark$ & $\checkmark$ & $\checkmark$ & $\checkmark$ & $\checkmark$ & & \\
\hline Skånegatan & Small & $\checkmark$ & $\checkmark$ & & $\checkmark$ & & & & & $\checkmark$ & \\
\hline Stortorget & Small & & & & $\checkmark$ & & & & $\checkmark$ & $\checkmark$ & \\
\hline Stu regatan & Middle & $\checkmark$ & $\checkmark$ & $\checkmark$ & $\checkmark$ & $\checkmark$ & $\checkmark$ & $\checkmark$ & $\checkmark$ & & $\checkmark$ \\
\hline
\end{tabular}




\begin{tabular}{|l|l|l|}
\hline Shops & Price range & Volume of items \\
\hline Hagagatan & Low to Medium & Middle \\
\hline Hantverkargatan & Medium to High & Middle \\
\hline Hornsgatan & Low to Medium & Middle \\
\hline Liljeholmsgallerian & Middle & Middle \\
\hline Lövholmsvägen & Low & High \\
\hline Skånegatan & High & small \\
\hline Stortorget & High & small \\
\hline Sturegatan & Low to Medium & Middle \\
\hline
\end{tabular}

In every store, they sort out the assortments by category. In the category, they sort out by colors to look neat. Every store uses the technique of displaying items sold the most and on the table closet to the entrance. They place items they want to sell or seasonable items. They change the show window in Hantverkargatan store every week. They receive new items from warehouse every day. They have to change the layout of the store very often. They reduce price in the middle of the season so that they can sell very well. I saw summer clothing stock in the warehouse because people donate summer clothes in winter time. But I didn't see stocks to sell. I asked the person in charge of the warehouse, she said they didn't have stock, they could sell every item.

\subsubsection{Problems in stores}

The stores I worked in, I asked store managers (Ms.Linda Hallin, Ms. Erika Rougeux) and workers (Ms.Sanna Nyman, Ms.Liza Hallin) what they want to improve or what they feel troubled in the stores. I found out by the questionnaire, workers at City Mission are satisfied with their work and work environment. However, they have few parts want to improve in the stores. 


\section{- $\quad$ Need more store fixtures}

Many store managers have this problem. The store fixtures are mostly old, fixed with packing tape. Sometimes they are used from donations. To show garments and make other products look better, stores need to have new store fixtures. I heard they have a budget for store fixtures but it seems the budget isn't used so much. I saw many damaged silver fixtures to hanging on jackets, pants and shirt.

\section{- Some people leave donation items after store working hours}

As I mentioned earlier (3.2.1 Problems at the warehouse P.7), this is a big problem in bigger shops such as Lövholmsvägen. Donations are accepted in the shops (Picture: 15). People have to come to the store during the opening hours to donate. Some people come after the store closed. If it rains or snows the gifts get wet. City Mission put up the advertisement to ask people not to donate after the store has closed before but it was not effective.

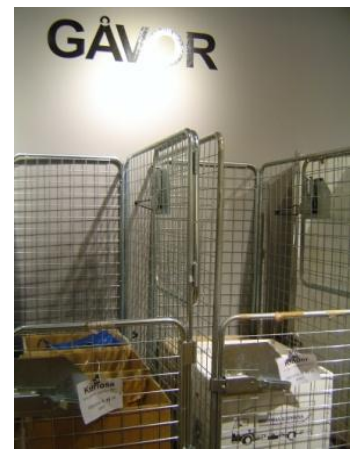

Picture: 15

\subsection{Remake}

They annually receive 16 tons of textile and garments that companies can't sell. They also receive many second-hand materials from citizens. They use this opportunity and give the left over garments and textiles a new life as second-hand remade. They've been working on expanding the section since 2008. Stockholm's City Mission's remade section is quite new. Their

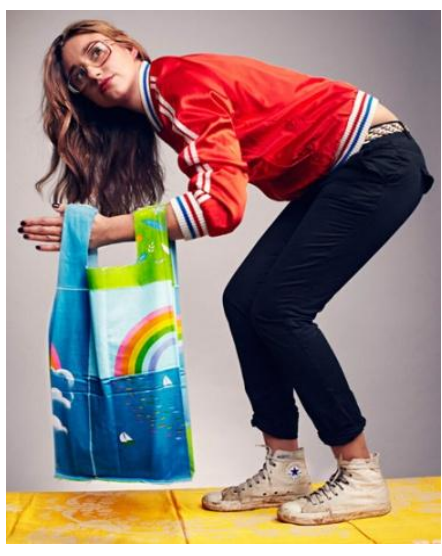

Picture: 16 
remade process is very unique in that they have their own factory in Stockholm and provide work for the city's homeless or vulnerable. (6) Their second-hand remade products aren't very cheap. Their first priority is not selling with a lower price. Their aim is to help people and contribute to the society.

They have started a new project in the remade section in May 2009. They collaborate with a designer and made shopping bags. They made a shopping bag out of a new garment which the company couldn't sell. The designer of

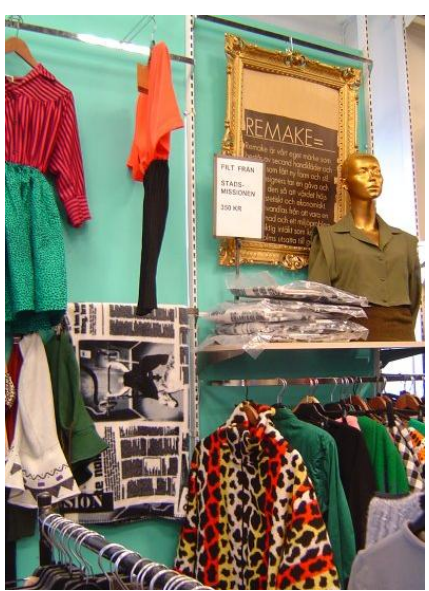

Picture: 17 Remade garments

the plastic bag is "Claesson Koivisto Rune" (Picture: 16). This design group designs furniture, kitchen ware, bathroom products, textile and jewelry. (7) Claesson Koivisto Rune shopping bags and other home textile such as cushion covers and small purses are made in Stockholm and give to homeless and people who needs vocational training.

The remade clothes are made in the back of the Hornsgatan store. There's one designer working and the other workers are coming to work for vocational training or as a social service. There's another production workplace to make for cushions and small purses in Stockholm. All of the remade products are handmade. Sometimes they can use very expensive fabric such as from Vivienne Westwood. City Mission remade is not only garments, but also furniture and jewelry. They remake furniture with donations from Åhléns and other materials. They remake furniture in the warehouse then sell it in Gamla Stan and Liljholmengallerian stores.

City Mission's remade products aren't cheap but it's handmade and the money is used for a good cause. City

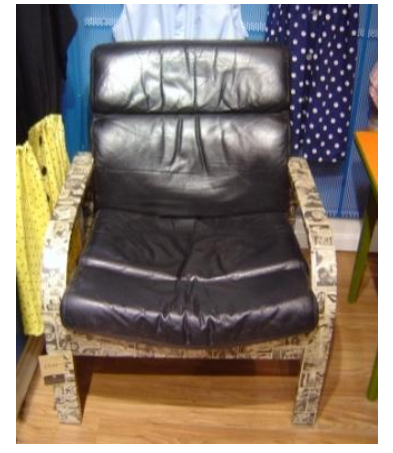

Picture: 18 Remade furniture

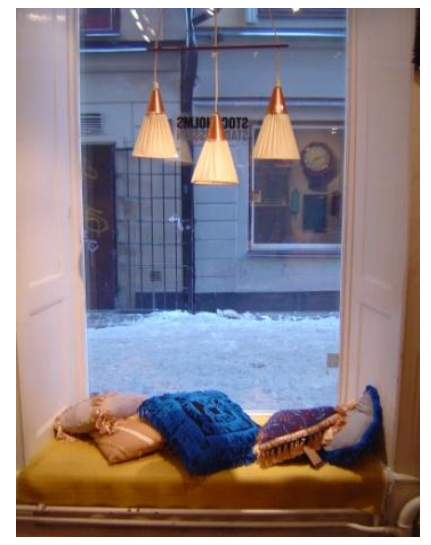

Picture: 19 Remade home textile

\footnotetext{
${ }^{6}$ http://www.stadsmissionen.se/Secondhand/Remake/Tygkassen/

${ }^{7}$ http://www.ckr.se/
} 
Mission has expanded remade section and renovated Hornsgatan store.

Now they're selling remade clothes, furniture and jewelry as of May 2010.

(Picture: 17, 18, 19)

\subsubsection{Problems in the remade section}

\section{- Fewer workforce}

There's only one designer to remake garments and the other workers who remake garments or bags are vocational trainees, volunteers and young people doing social service. They don't come every day and for a whole day. The workforce for remade products isn't stable. The designer has to teach how to make remade products to other workers every time they come in. It is a waste of the time. At the same time the designer has the task to make seven garments within a certain time line. The situation for now is that the designer has to take care of everything and has less time for creative work

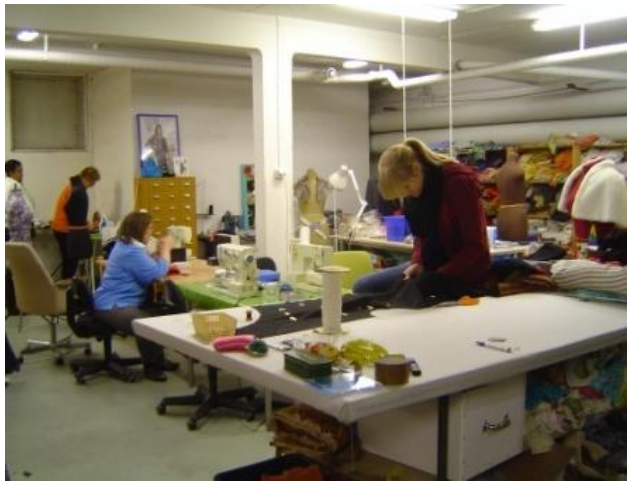

Picture: 20 (Picture: 20).

\section{- Unfavorable working conditions}

Fewer workforces is one of the unfavorable working conditions, but also the work area is inadequate (Picture: 21). There is no window and it's very cold in the winter time. The designer is trying to sort out fabrics to make it easier to use at the present time. The designer till March is a substitute designer of who has been in maternity leave. She works only $40 \%$ then it is very hard to keep the business on track. From this April, the former remake designer will come back.

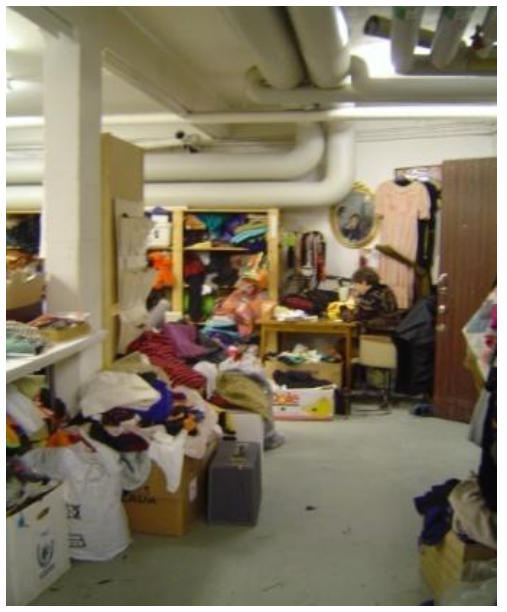

Picture: 21 


\section{- Remade garment's design is too unique}

The lineup of remade garments in Gamla Stan store which used beautiful Swedish designer's textiles. It attracts tourists. On the contrary, in Skånegatan shop, remade garments are not selling well. According to the store manager (Ms.Linda Hallin), the sizes are for very tall and thin people. The average person can't fit the clothes. Also, the design is too unique, and the price isn't cheap (Picture: 22). I think they can't change the price range for remade garments since they are handmade and it is for good cause. But they can improve the design. If the design is accepted by the majority of people, they can expect more sales in remake garments. They can increase remade home textiles especially with small purses since these are very popular among tourist (Picture: 23 ).
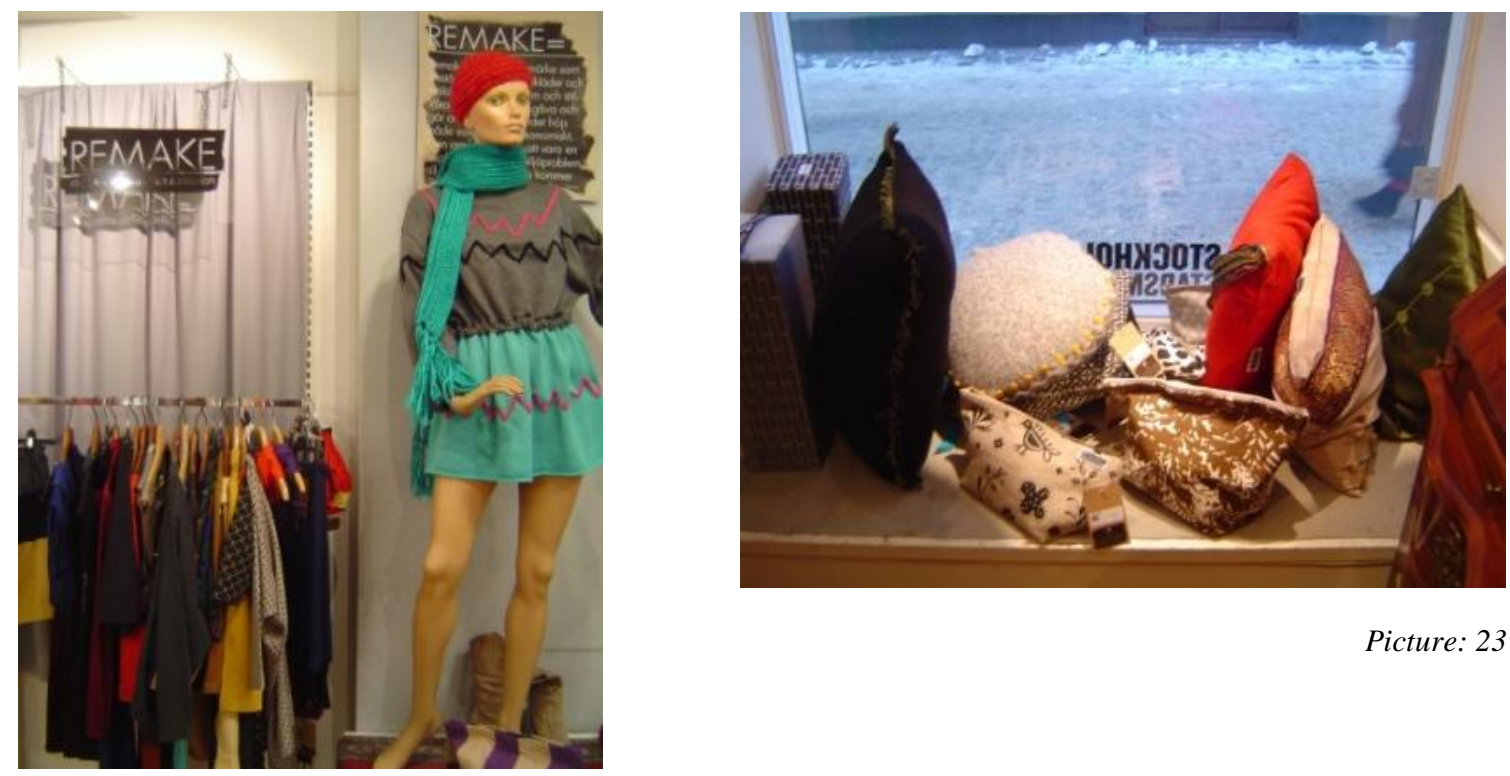

Picture: 23

Picture: 22 


\section{ANALYSES: SALES FIGURE}

\subsection{Current situation}

Their top sales are in women's wear, dish ware and media (Chart: 4). Media includes CDs and DVDs. The biggest and oldest store, a low priced and high volume store, Lövholmsvägen, has top sales every month. The second highest store is the low to middle price- ranged Hornsgatan (Mariatorget: MTG) store. The most popular items being sold at these stores are; Gamla Stan store (STG) is selling dish wear the most.

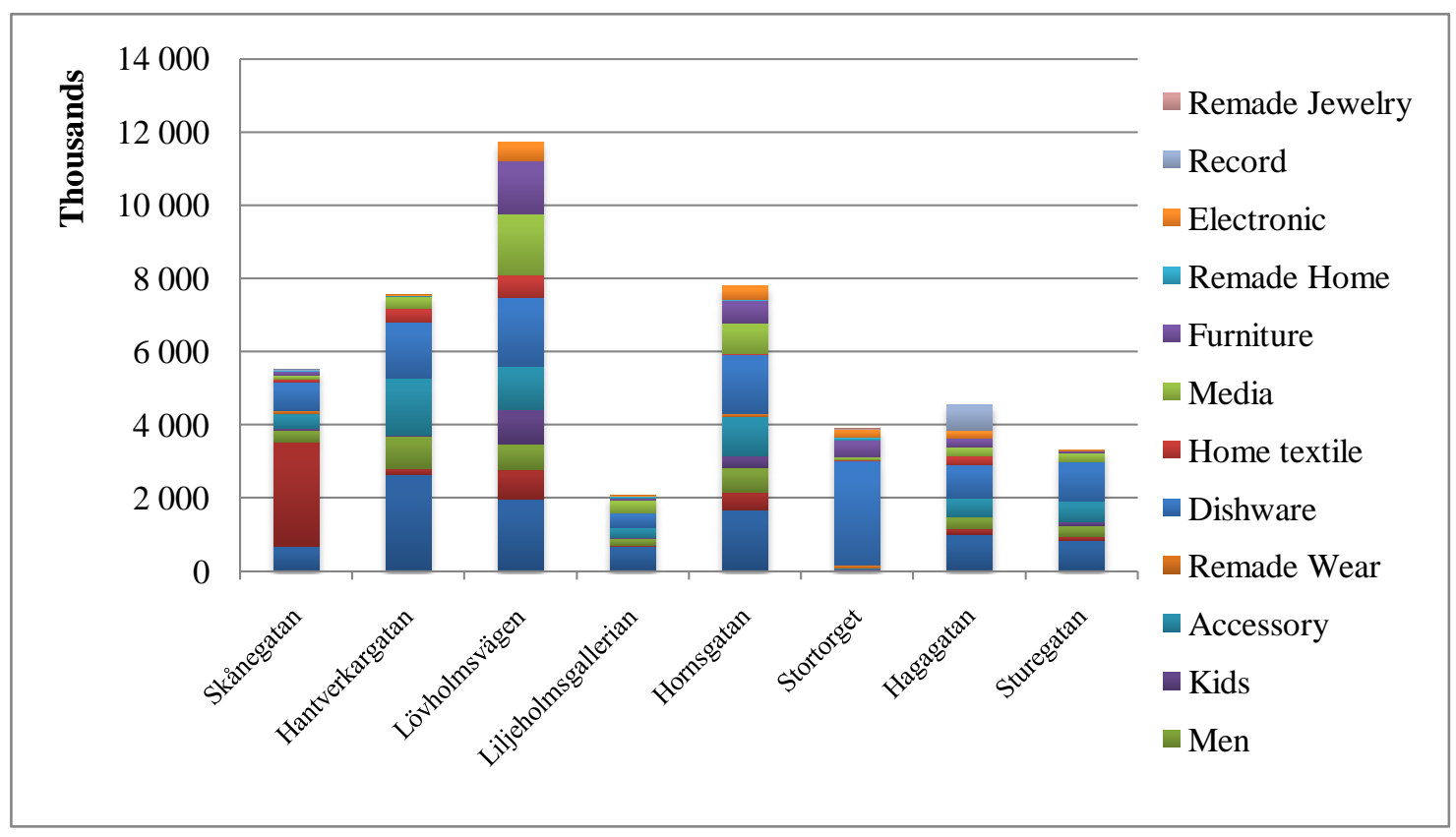

Lövholmsvägen is selling media the most. They have a big CD and record display. Hantverkargatan is selling women's wear the most. City Mission changes the stores' layout according to the sales figure. Tops sales are always close to the entrance.

Talking a look at their sales over the year, their sales have been increasing each year (Chart: 5). One of reason is that City Mission has opened new 
stores for these three years. The number of stores has increased from 6 to 8 in the last three years. A number one sale is woman's wear, second is Dishware, and third is Accessory (bags, shoes and belts). The lowest is remade wear and remade home textile. The reasons why these categories are low in sales, one of reason is that it has been only few years since remade section started, consumers don't know about remade. Another factor is the price is higher than other garments in the stores. Second-hand shirt price around 65kr, brand name second-hand is around $150 \mathrm{kr}$. On the other hand the remade clothes are from $250 \mathrm{kr}$. If they pay $250 \mathrm{kr}$, they can buy new clothes at H\&M at a cheaper price. They need express to consumers special attraction which H\&M doesn't have; Sustainability or ecological and help the local society.

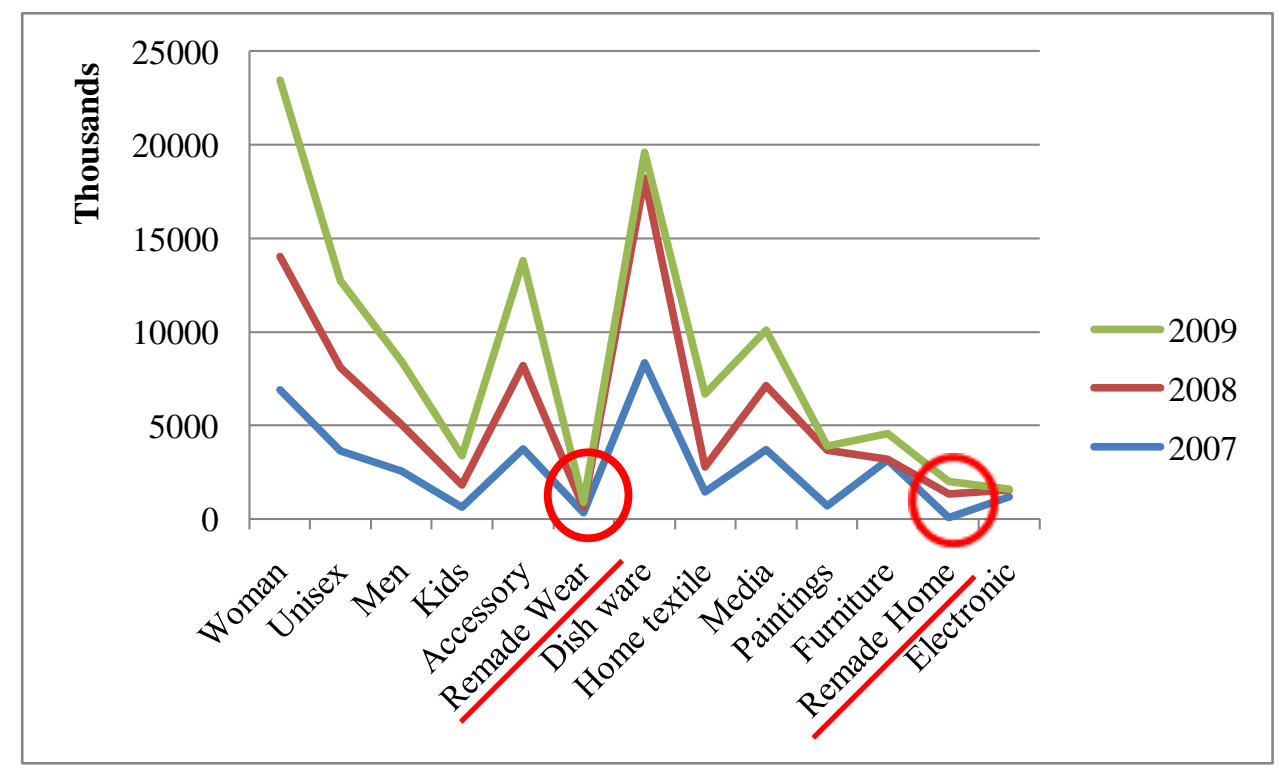

Chart: 5

Taking a closer look at remade wear and home textile (Chart: 6). Compared to remade clothes and remade home textile, remade home don't experience significant changes but it is slightly decreasing. As for remade clothes, it was increasing a lot in 2008 because of the shopping bags. But it's decreasing in 2009 by half. A possible reason for the decline in sales is that the person who started the remake section has been on maternity leave. The substitute designer works only $40 \%$. Another possible reason is 
that the designer collaboration shopping bag isn't selling as well as they expected after 2008. Other reasons are price and design which I mentioned in the section above.

Chart: 6

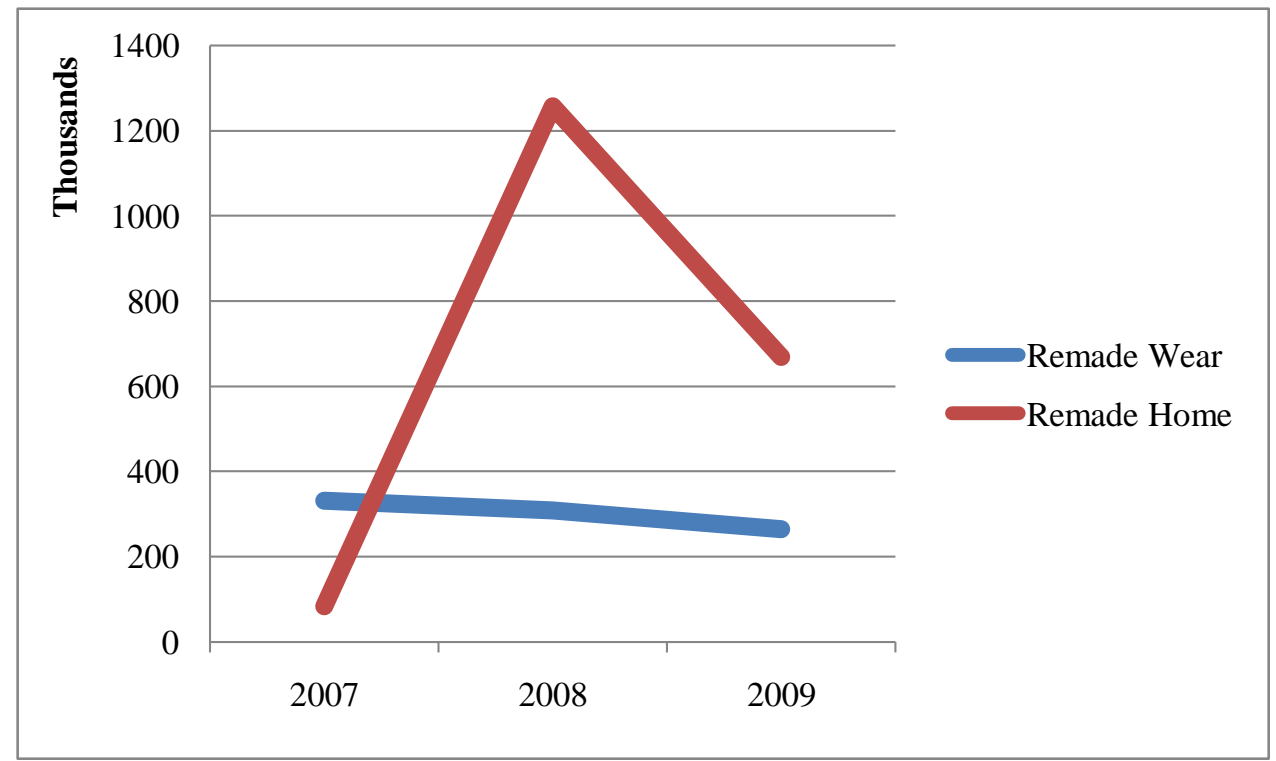

\subsection{Suggested Improvements}

It is not easy to increase menswear sales because City Mission hasn't received enough menswear. It needs to let people know the fact that men's wear is less and they need more. There are other things we can improve. Remade wear's improvements are design and price. Also it takes time to let people know about it and it needs many ways to improve. I assume that remade home textile is rather easy to improve. Home textile tends to be easy to make and easy to buy because customers don't need to try them on. Home textile sold increasingly very well in 2008 , I assume if they make more home textile, and increase assortment, remade home textile has a good possibility of better sales figures in the near future. 


\section{DISCUSSIONS}

After analyzing the situation of City Mission, and seeing what I can do to grab more attention from people on the topic of sustainability, I have some thoughts about the best way for City Mission move forward in the future. As I wrote earlier, sustainable fashion should mean using ecologically, ethically good products that are made locally. It seems like City Mission has done very well in these three categories. During my field study, however, I could see some problems in the working environment, for example the room for the remade section. Additionally, I've seen some other things we can change or improve - for example, they don't have enough garment donations. I read an article in METRO in early 2010 that H\&M in New York throws away garments they can't sell. This is clearly unsustainable, and $H \& M$ could have instead donated to somewhere. I called H\&M in Sweden (Ms.Gilljam Nathalie), Gina tricot (Ms.Elin last name unknown), IKEA (Ms.Karina Angwald and Ms.Shubhra Bhattacharya ) and WESC (Mr.Anders Heden and Mrs.Jane McAndrew) to ask for donations. H\&M in Sweden and, Gina tricot already have contracts with other organizations concerning donations. Although I sent reminders many times to IKEA and WESC, I never got a reply back from them. What I can do for City Mission is that I can work on improving the remade section, and I hope it helps to get more attention from people and companies to donate to City Mission.

I decided to focus on improving the remade section. Remade design should be able to add ecological value; people who wear the garments can feel good by wearing them. They contribute to the environment and society. Many young women and men have a stress to express their identity with fashion. (8) City Mission can add another value which makes people who wear it feel good, feel doing something nice to the environment and society, and I believe this is an important strategy for City Mission's remade section to adopt. But at the same time as Sofia Minney said in The Design of

\footnotetext{
${ }^{8}$ Fletcher, K.(2008), Sustainable Fashion \& Textile Design Journeys, London; Sustainable Fashion and Textiles, p118
} 
Prosperity 2006, "Ethical and ecological products don't need to look boring, nor ugly." (9) Thus design plays a big role in sustainability in fashion. One eco-fashion designer, Deborah Lindquist, said "Partnerships and joint ventures are important, as are collaboration of ideas, social media, and networking. I feel that it's the perfect time to team up with someone to create a new idea. We need to help each other and focus on our individual strengths to make our businesses stronger and thereby create a stronger green community." (10) Hence collaboration with designers is a key for sustainable fashion. I would like to begin from what I, personally, can do. I came up with some ideas; collaborating with young designers to make printed T-shirts, collaborating with fashion design students in The Swedish School of Textile to create remade second-hand garments. For the other aspect regarding "helping each other", the second-hand and remade business is huge but it is not run by profit-making business. I believe they can learn from what Stockholm's City Mission does for its community.

During my field study period, I got to attend Stockholm fashion week and I had a chance to go to the ecological fashion show. The show was intended to advertise a new project; a clothing library called "Lånegarderoben" (11). Many second-hand organizations and stores participated in this project and Stockholm's City Mission is one of the biggest donors for the library. The concept for this already existed in other countries such as the UK and, Japan. In Japan, the idea is a rental Kimono or Wedding dress. Companies rent out expensive clothes to customers. This project was the first in Sweden. You can rent the garment for a week, and you don't need to wash them before returning - the company takes care of the garments (12). The library concept involves renting out clothes designed for special occasion, rather than everyday life. As you can see in the pictures below (Picture: 24, $25,26,27)$ some designs are very unique. I took a look at the garments

\footnotetext{
${ }^{9}$ http://www.thedesignofprosperity.se/speakers.asp?id=5

${ }^{10}$ http://www.ecouterre.com/9045/16-eco-fashion-predictions-for-2010/

${ }^{11}$ http://www.lånegarderoben.se/

12 http://www.goodlifer.com/2010/03/clothing-libraries-a-shift-from-wasteful-to-resourceful/
} 
available for me to borrow, but almost every garment was very unique. This is a good service that allows people to wear unique designs which they wouldn't buy themselves. They can wear it just for fun without paying so much money. The library accepts donation from citizens as well. This is a new way of recycling.

I mentioned earlier that City Mission's remade garment designs are too unique and these garments might end up as garbage. Even if these are used in the library, if they fit only a model's body type, they may end up as garbage anyway, but it's worth giving them a chance to be worn by someone. I was happy to hear that they opened the clothing library. Although I still believe we need to have a good design for City Mission's remade garments to be able to be accepted by the consumers.

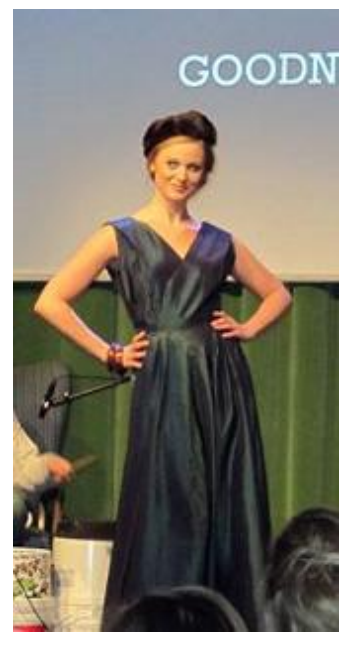

Picture: 24

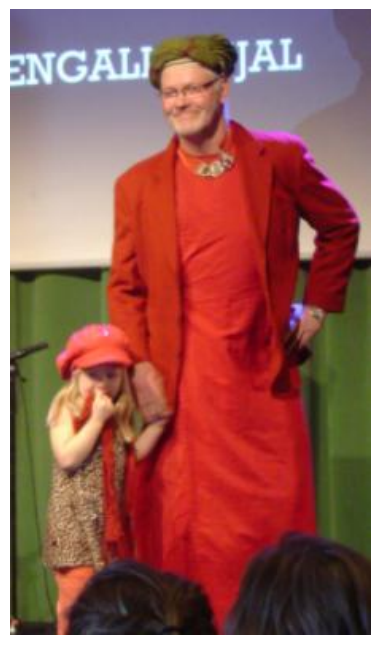

Picture: 25

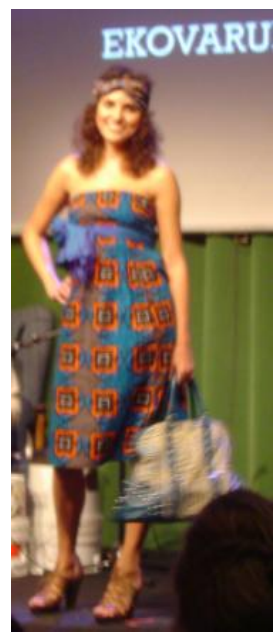

Picture: 26

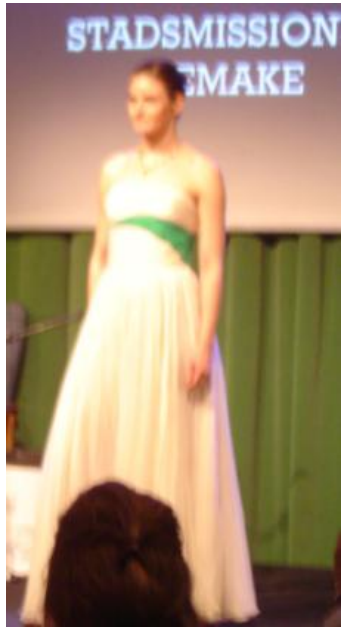

Picture: 27 


\subsection{PROJECT 1: Remade T-shirt collaborate with young designers}

\subsubsection{Project Concept}

The concept of the project is to see how design, especially graphic design, and illustration effect sustainable fashion. Printed T-shirt is very popular; some companies are successful selling only printed T-shirt, such as T-shirt store in Sweden. They produce T-shirt with 100\% ecological cotton (13).It would be more ecological to sell second-hand T-shirt: from which the profit is used for helping people.

To be successful in art field as artist is not easy thing to achieve. This is a good chance for artist to show their work to the world. Stockholm's City Mission's second-hand is quit famous in Sweden. People know City Mission has done a good thing for society. This is a good advertisement and good image for the artists and entices them to participate to the project.

\subsubsection{Method}

This project will feature one designer per month. The artist will make three designs. They won't get paid by City Mission but they can exhibit their work in the stores and display their business cards so that customers can follow them. City Mission will produce 100 copies of each design and sell in Hornsgatan store (which has the biggest remade section) and Skånegatan (which deals with trendy brands). The T-shirt design information, designers' biography and website link of the designers will be put on the City Mission's website. For the project launch, City Mission will put advertisement in a magazine or paper. I picked up designers from in and outside of Sweden, to make the idea more interesting and one that is the essence of sustainable fashion: "help each other". Basically, designers can design

\footnotetext{
${ }^{13}$ http://tshirtstore.se/
} 
whatever they want, following some rules: color for the T-shirt is kept to 3 to 5 colors. Each color costs, so more colors equal a higher production cost. I consulted to the supervisor of City Mission and they can't afford too many colors on T-shirts. The next rule is the designers should be careful what the message they include in their designs. T-shirts will be produced under the name of Stockholm's City Mission. People think that the message is from City Mission or that City Mission supports the idea. If it's not a good message, it'll be a problem. Also, as I mentioned in earlier in the problem in remade section (4.2.1 Problems in the remade section: "Remade garment's design is too unique" P.16): if the design is not good, it won't be sold and go to garbage. It has to be in a good design. Before we produce them, we need to examine the design and decide if it will produce good sales or not.

\subsubsection{Process}

It was fortunate to have some friends, in and outside of Sweden, working as designer and artists for the project. There are five participating designers from Japan, Sweden and Denmark: Jesper Olsson (Sweden, Picture: 28), Ayaco Nakamura (Japan, Picture: 29), Leolyxxx (Sweden, Picture: 30), Basco5 (Denmark), Sam Hallin (Sweden). I encountered many problems pursuing this project's completion. The first problem was with design. One of designer put a gun illustration in the design. The chief supervisor of City Mission's second- hand (Mrs. Janna Hellerup) said they couldn't have a gun in the design because then it seems like Stockholm's City Mission supports gun. One of designer designed T-shirt with a good story; lost home, on the street and saved by Stockholm's City Mission (Picture: 31 ). He described it in three designs. Although I wasn't sure I couldn't sell out 300 copies (100 copies of each) with the design. I asked 10 people I know if they would want to buy the T-shirt or not: men and women, 20s/30s/50s, from Sweden, Germany, Japan and Australia; and who have different taste from each other. None of them said they would want to buy the shirts and that it wouldn't be their first choice. Most of them pointed out that it didn't work as separate design ideas but altogether the 3 designs would portray 
the story. Some said it would be better more colorful but to have colorful Tshirts is very expensive; it is impossible for City Mission. It was very hard to ask the designer to redesign but I can't produce T-shirts that I am almost sure won't be sold. I can't waste City Mission's money either so the best way was to change the design.
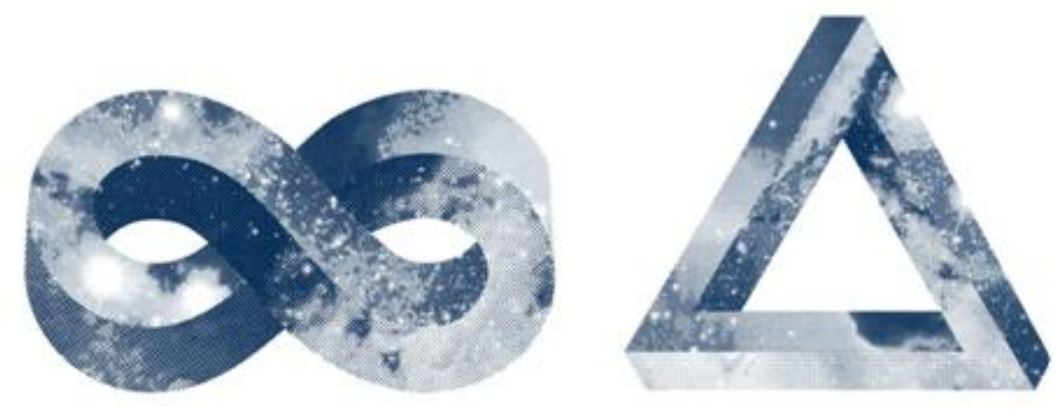

Picture: 28 Jesper Olsson

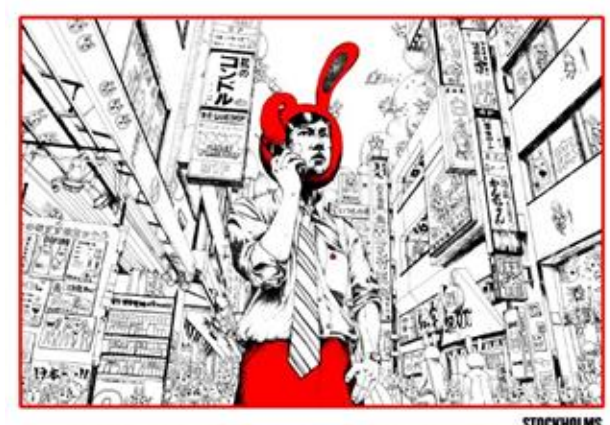

THERE ARE TRICKS IN EUERY TRADE. STIOCSHOMS

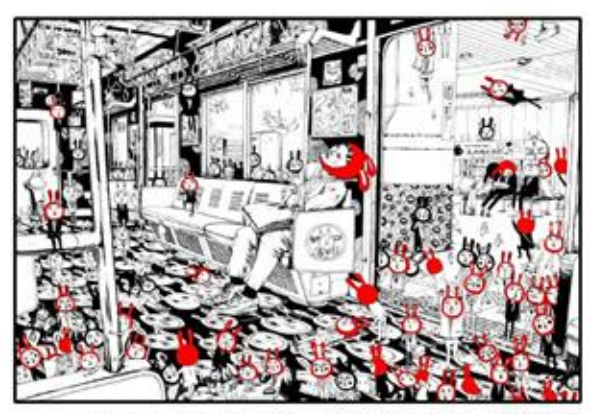

HEALTH IS BETTER THAN WEALTH. SHPCOMOUS

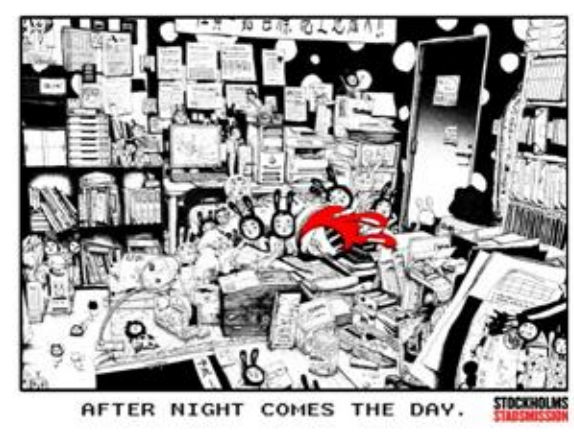

Picture: 29 Ayaco Nakamura 

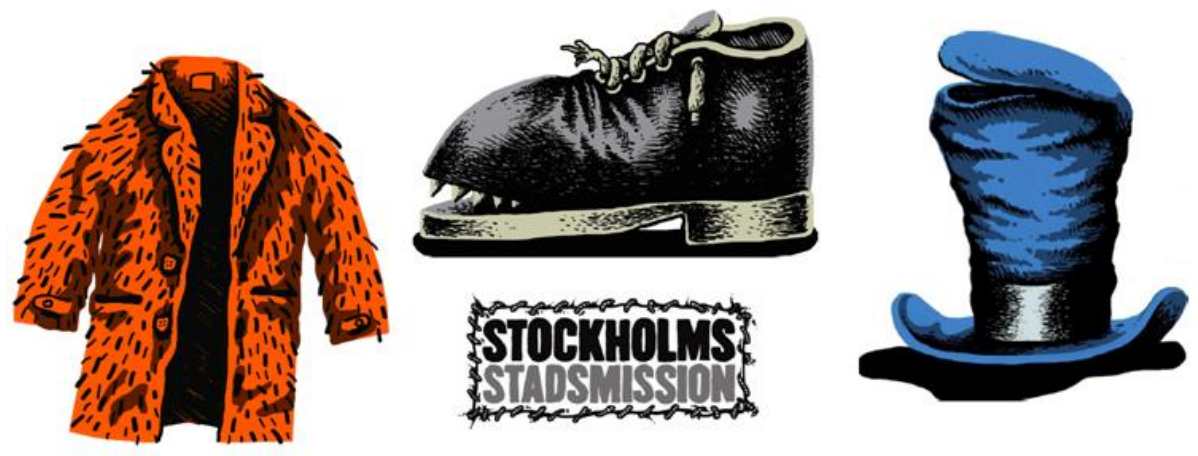

Picture: 30 Leolyxxx

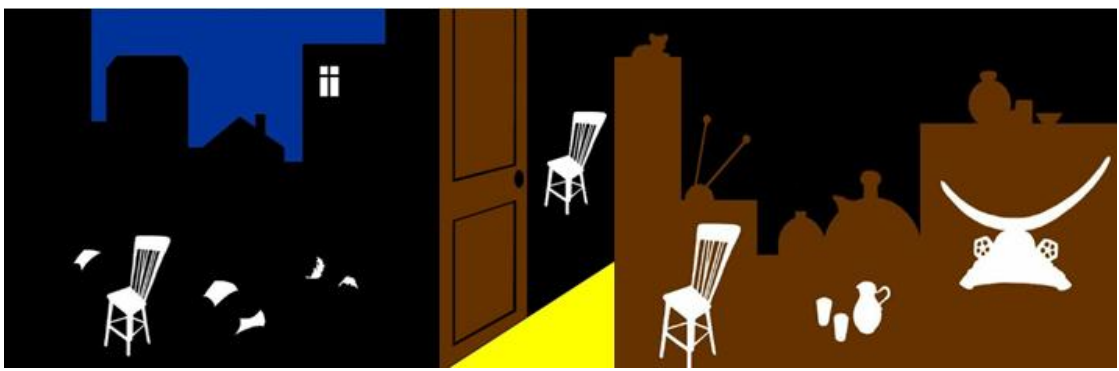

Picture: 31

The second problem I ran into was advertising. The Japanese designer expects a lot of advertisement. But City Mission couldn't give many advertising than the designer expects. I thought City Mission could make more advertisements or they could use more PR budget for T-shirt project because they didn't need to pay for the designer. I talked about it with the supervisor of City Mission's second-hand (Mrs.Janna Hellerup). She told me it is very expensive to put a small advertisement on well-known magazines and papers - it costs more than 15,000kr. They don't want to spend that much money every month. I understand the reason. In the end, I figured out the designers can get exposure on Stockholm's City Mission website. If they are lucky enough to be picked by some magazines or papers for interview, it will be their advertisement. Stockholm's City Mission is often picked up in some magazines. Also well-known organization, people will get to know that City Mission is collaborating with designers to make the T-shirt; people will come to the store and it is good publicity for 
young designers. I figured I needed to emphasize to designers that the work is voluntary and for a good cause.

The third problem I had was when I was hunting for designers. The Swedish have a better understanding about City Mission and they are willing to work for them because it is a good cause. However, some Swedish designers got angry when they heard they will work for free. Also, it was very hard to explain to the designers in another country. I had to tell them how big Stockholm's City Mission is, how famous they are etc. The Japanese designer is very eager to be successful. She pushed too much about getting her into some magazines or advertisement. I told her Stockholm's City Mission is NGO. The profit is meant to be used for helping people, not to advertise the artist.

The fourth problem was collecting second-hand T-shirt. We couldn't collect enough second-hand T-shirt. We needed to buy new T-shirts to sell on the release date, which was the Hornsgatan store reopening on April $8^{\text {th }}$. The initial plan was to use only second-hand T-shirt but City Mission couldn't collect enough. They could collect half of the needed amount, 100. The supervisor (Mrs.Janna Hellerup) decided to purchase new organic cotton Tshirt from England. We could cover women's size because we have enough donations, but we had to buy new T-shirts in Men's sizes.

The fifth problem was with printing. City Mission doesn't wash clothes to sell. The initial idea was not to wash them and just print on them. But according to the third party printing company, if we print on a T-shirt that has dirt or stains, the print will come off after its first wash. So we decided to wash the T-shirt before print them. 


\subsubsection{Result and Analysis}

Thanks to the project's release day being the same day as Hornsgatan's renewal opening, there was more advertisement for the project than I expected. They put advertisement in METRO about the store opening. (Picture: 32). The renewal opening was held on April $8^{\text {th }} 12: 00 \mathrm{pm}$. So many people came and bought a second-hand item and the T-shirt. There was a long line up at the cashier on that day. The designer's exhibition space was smaller than I expected. The designer made two posters himself. It costs $160 \mathrm{kr}$ for each print. City Mission didn't want to pay for the poster print, so that the designer had to pay for them but one of customer wanted to buy the poster.

\section{VÄLKOMMEN

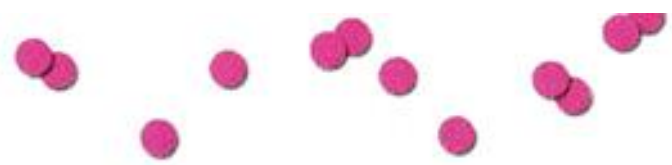

Pă torsdag den 8 april ki 12.00 är det premiär för vâr omgjorda butík på Hornsgatan 58. Dả kan du:

* kōpa unika t-shirts qiorda av internationella designers frăn THE T-SHIRT PRO.JECT

† kolla văr nya REMAKE-avdelning med omgjorda secondhandmôbler och -kläder

$\checkmark$ hitta massor med bra erbjudanden

Vi bjuder pâ dricka och tilltugg för att firal

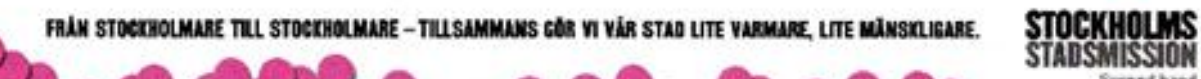

The artist was allowed to sell their work in the store as well. (Picture: 33, $34,35,36)$ Press person from METRO came and I was interviewed about the T-shirt project. The article was in the paper in the next day (Picture: 37 ).

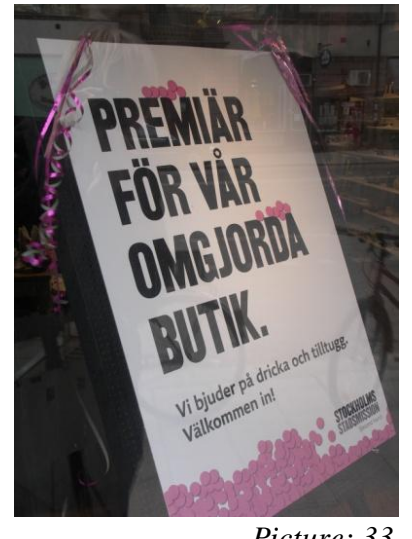

Picture: 33

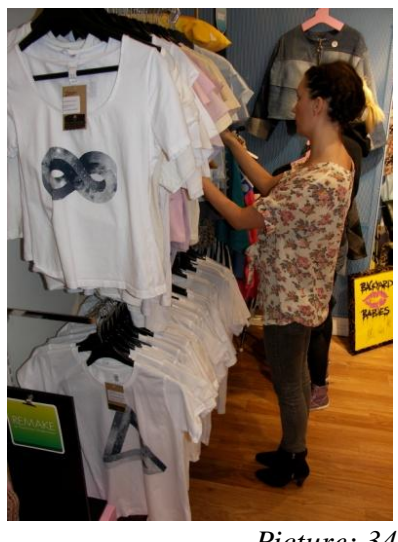

Picture: 34

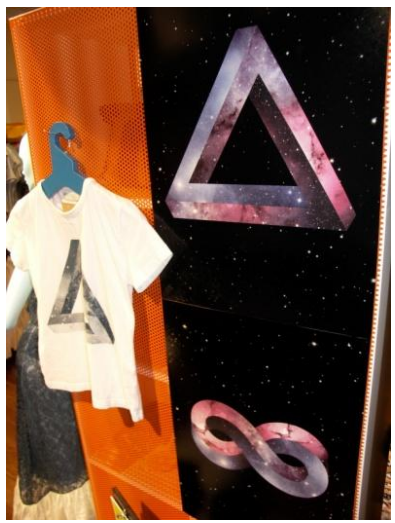

Picture: 35

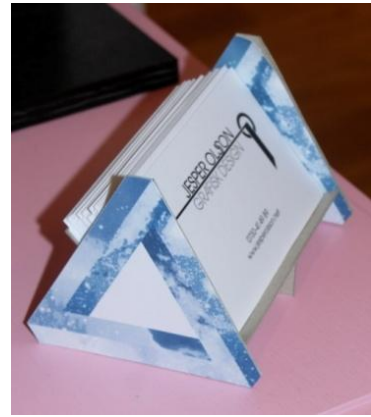

Picture: 36 


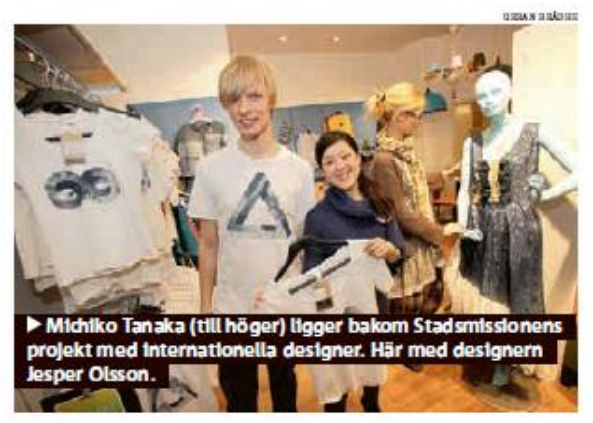

Här blir gamla t-shirtar till designerplagg

Stadsmissionen nyinviger vid Mariatorget - och satsar stort genom att göra om gamla t-shirtar till designerplagg.

Fem designer frân olika hâll i världen har skapat varsin t-shirt. Hälften är vintage. Hälften i ekologisk bomull. Miljötānket ligger i tiden. liksom satsningen pả internationella samarbeten.

-Vi ville ta vara pà de tha grejer vi far in pà nà-

Bâde for att bidra till mindre sopor och for att fa mer pengar till vàrt sociala arbete, berattar Janna Helhetschef for Stadsmissionens stödjande affärsverkamheter. Jesper Olssons design. - ania OBMmsRa
I suspected that April's remade section sales would increase to be double as much as they used to. As you can see in the chart, sales doubled as I expected (Chart: 7).

Remade sales have increased because the remade section has expanded for Hornsgatan renewal opening. Now they have two designers; they hire a new person who can work constantly in the remade section. They made many garments for the Hornsgatan opening. The design of the second-hand changed to become more colorful and more dresses are in the assortment that is easy to try on (Picture: 38). Also they started to make baby clothes with kitchen cloth. Baby clothes have very good design. (Picture: 39) They made more small purses in different sizes.

They hired social worker to teach how to work, how to operate the sewing machine to the workers in remade production. Workers in production might have some problems in their mind. It is good to be taken care of a specialist and reduce work for remade designers.

I discussed why the T-shirt sale wasn't the first reason for the increase with remade designers (Mrs.Marie Teike and

Ms.Pernilla Rozenberg).

Picture: 37

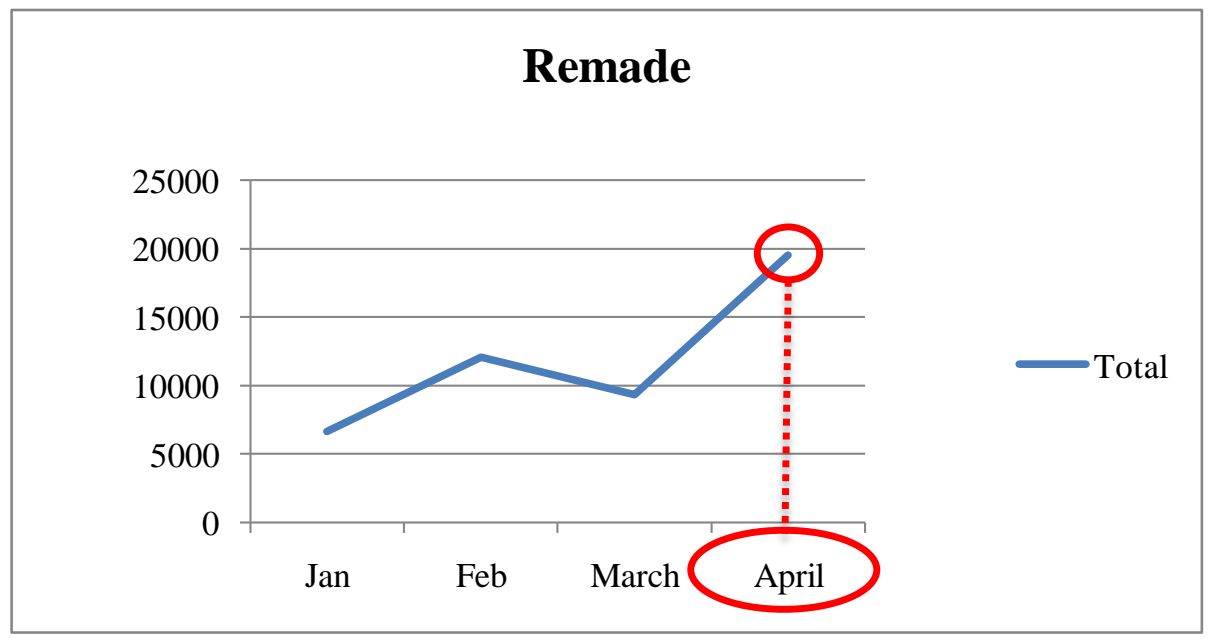

Chart: 7 

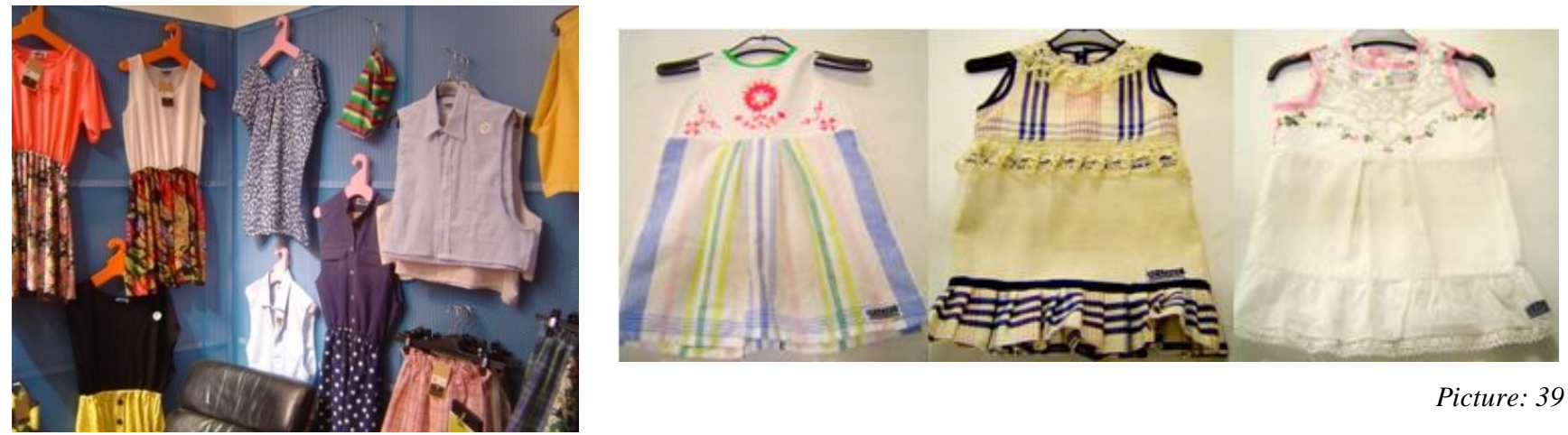

Picture: 39

Picture: 38

We concluded that the assortment of the size wasn't good. This time we had a lot of women's sizes. The female customers of City Mission are around middle age in Hornsgatan. They don't buy printed T-shirt. The least we can do to sell the T-shirt, is to spread the T-shirt to the other stores. I asked the supervisor but it hasn't done yet. As the first T-shirt sales were not good as we expected, in the second time we decided to print on only in second-hand T-shirts and tank tops, 150 copies in total which means one design can have 50 copies.

Young men are good customer for the printed T-shirt market; in order to win the customers, it is necessary to have advertisements. I thought a free paper called PEOPLE is the best paper to have advertisement (Picture: 40). PEOPLE isn't big as METRO, not everyone takes a look at the magazine but the reader of PEOPLE is the exactly the target City Mission needs for T-shirt. I assume that if we put the information about the collaboration Tshirt with designers, the target group will pay more attention to City Mission. Unfortunately, it is too expensive to buy the advertisement in PEOPLE; City Mission could give the T-shirt project a chance to put T-shirt advertisement in Nöjesguiden instead.

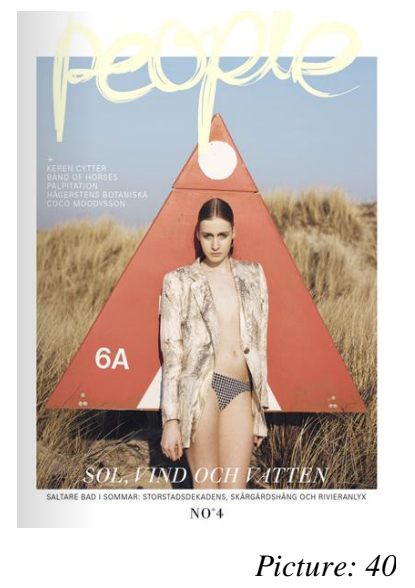




\subsubsection{Improvement points}

The project was to get people's attention to sustainable products. Also, the project is supposed effective at getting new customers. This project will be a regular project. To make this project to run easily, it is best to have clear instructions or terms in the document including what designers can get in return. For example, this time it was a problem that one of designer drew guns, knives and blood on T-shirt design. To avoid the work, better to have some clear instructions for designing. The instructions need to have deadlines for every step, one for designer and one for production. (Chart: 8, $9,10)$

T-shirt release date: 10 th of everymonth

Chart: 8 Deadline for designers

\begin{tabular}{|l|l|c|}
\hline \multicolumn{1}{|c|}{ Tas ks } & \multicolumn{1}{|c|}{ Date } & Example: Release date May 10th 2010 \\
\hline $\begin{array}{l}\text { Send design files } \\
\text { (In "*eps" and "*jpg") }\end{array}$ & 10th of previous month & April 10th \\
\hline $\begin{array}{l}\text { Send modified files } \\
\text { (As needed) }\end{array}$ & 25th of previous month & April 25th \\
\hline $\begin{array}{l}\text { Send business card files } \\
\text { (nn "*word" or "*pdf. Paper format is A4, 10 } \\
\text { business cards in one sheet) }\end{array}$ & End of the month & April 30th \\
\hline Designer's works for exhibition & $\begin{array}{l}3 \text { bus iness days prior to the } \\
\text { relase date }\end{array}$ & May 5th \\
\hline
\end{tabular}

T-shirt release date: 10 th of everymonth

Chart: 9 Deadlines for production

\begin{tabular}{|c|c|c|c|}
\hline Tasks & Details of tasks & Date & Examp le: Release date May 10th 2010 \\
\hline \multirow{3}{*}{$\begin{array}{l}\text { Designs } \\
\text { ( } \mathrm{T} \text {-shirt and business card) }\end{array}$} & Exam ine the designs & 13 th of previous month & April 13th \\
\hline & Approve the designs & 27 th of previous month & April 27th \\
\hline & Make business cards & $\begin{array}{l}2 \text { business days prior } \\
\text { to the relase date }\end{array}$ & May 6th \\
\hline \multirow{2}{*}{ Collect T-shirt } & Collect T-shirt in ware house & Every business day & Every business day \\
\hline & $\begin{array}{l}\text { Send T-shirts from warehouse to } \\
\text { Homs gatan } \\
\text { (To count the T-shirts) }\end{array}$ & $\begin{array}{l}3 \text { business days prior } \\
\text { to the date to send to } \\
\text { the print factory }\end{array}$ & April 23rd \\
\hline Print T-shirt & Send T-shirts to print factory & 26 th of previous month & May 5 th \\
\hline
\end{tabular}


T-shirt release date: 10 th of everymonth

Example: May 10 th

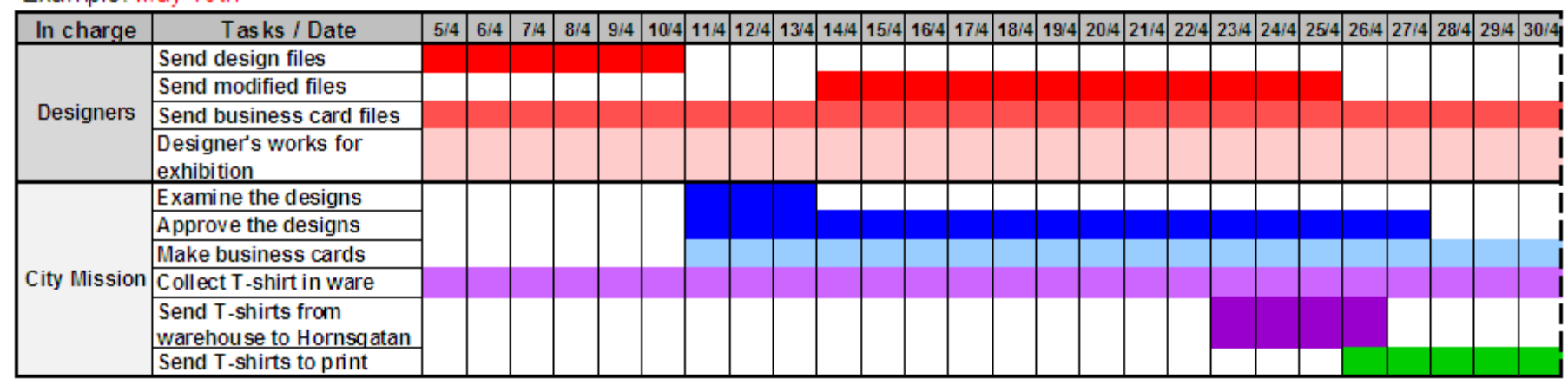

\begin{tabular}{|c|c|c|c|c|c|c|c|c|c|c|}
\hline In charge & Tas ks / Date & $2 / 5$ & 3,5 & $4 / 5$ & $5 / 5$ & 6,5 & $7 / 5$ & $8 / 5$ & 9,5 & 10.5 \\
\hline \multirow{4}{*}{ Designers } & Send design files & & & & & & & & & \\
\hline & Send modified files & & & & & & & & & \\
\hline & Send business card files & & & & & & & & & \\
\hline & \begin{tabular}{|l|}
$\begin{array}{l}\text { Designer's works for } \\
\text { exhibition }\end{array}$ \\
\end{tabular} & & & & & & & & & \\
\hline \multirow{6}{*}{ City Mission } & Examine the designs & & & & & & & & & \\
\hline & Approve the designs & & & & & & & & & \\
\hline & Make business cards & & & & & & & & & \\
\hline & Collect T-shirt in ware & & & & & & & & & \\
\hline & $\begin{array}{l}\text { Send T-shirts from } \\
\text { warehouse to Hornsqatan }\end{array}$ & & & & & & & & & \\
\hline & Send T-shirts to print & & & & & & & & & \\
\hline
\end{tabular}

It was hard to ask for participation from the designers from other countries because Stockholm's City Mission isn't known worldwide. I needed to explain and the website is the best tool to explain but the website written only in Swedish. To gain more international designers, City Mission needs to have English page. It is also effective to let other countries know City Mission's contribution to the society.

Another improvement needed is the designer should consider that T-shirt size City Mission can collect. Most of the second-hand T-shirts are in women's sizes. If the designer designs for male, it is hard to sell the T-shirt in City Mission. This information should be included in the instruction for designers to hand out in the beginning. 


\subsection{PROJECT 2: Collaborate with Fashion designs students of The Swedish School of Textile}

\subsubsection{Project Concept}

One of the main reasons that has caused problems in the remade section and affected the sales figures is the poor design of the product. We need to improve this problem. The fashion design department of The Swedish School of Textile has a good reputation and therefore it is a good chance to produce a fashionable design garment. At the same time it is a good for the students who participate in the project to see how their design will be accepted by the public.

One aspect of sustainable fashion is high quality so that the garment lasts for a long time, Even if the garment is partially worn, for example the lower sleeve edge, the company who sold the garment is able to fix it, such as Patagonia. However it is very hard to apply this method to Stockholm's City Mission. They use second-hand material and therefore this is not possible for City Mission at the moment. For the design concept of the collaboration, I took the idea from the design of Prosperity 2009, Yvon Chouinard, founder and owner of Patagonia, Inc., said the garment has to be multifunctional so that consumers can consume less, consume better. (14) The other writer also suggests "By designing and developing one product that performs many functions, the overall effect is that we can do more with less" (15). To have more sustainability, the remade garment has to have an attractive design and be multifunctional. The consumer can use the garment in another way thus making the garment's life cycle longer.

\footnotetext{
${ }^{14}$ http://thedesignofprosperity.se/2009/profiles.asp

${ }^{15}$ Fletcher, K.(2008), Sustainable Fashion \& Textile Design Journeys, London; Sustainable Fashion and Textiles, p154
} 


\subsubsection{Method}

The design students send us the sketch over email first then the supervisor of City Mission second-hand (Mrs.Janna Hellerup) and remade designers (Mrs.Marie Teike and Ms.Pernilla Rozenberg) will decide if they want to produce it or not. If they want to produce it, the design students send patterns and the made up garments (Sample garment) to City Mission. If the designer wants to give the remade designer specific instructions regarding how to make the garment, for example the material and color, they can include these descriptions as well. If there's no specific request, remade designer will pick up the fabrics for the garment themselves. Each designer designs one multifunctional garment. How many copies we make will be discussed after remade designer views the garment. If it is not hard to make and if there's high demand from customers we will consider producing more garments. The fee to send patterns and the made up garment is paid by Stockholm's City Mission. The remade designers (Mrs.Marie Teike and Ms.Pernilla Rozenberg) can make contact with the fashion design students freely. The same as T-shirt project, design students work voluntary; their profiles will be on City Mission's website. City Mission has a fashion show in June every year. The fashion design students can expect to take part in the fashion show.

\subsubsection{Process}

I sent mass mail (through professor Pia Mouwitz) to fashion design students to ask participation to the Stockholm's City Mission project. I got four applicants but two of them are very busy with their new class assignment and had to remove from participation. I have two designers, Evelyn Lebis, first year master student from Netherlands and Miguel Lucas bachelor exchange student from Portugal. Evelyn sent us the picture in below (Picture: 41 ) It looks like a scarf made with jersey. She sent us the made up garments and patterns and found out it was not only a scarf, there were two scarves, one pair of trousers and one dress, all of them made with a jersey material with no description included, we were at a loss but 
remade designers and I talked about the garments and concluded that City Mission can produce one scarf which looks like a big baby bib. This is the only thing that we thought we might be able to produce with another material other than jersey. Although there was a point we need to consider producing it. At the time we received it there was no description included we would decide produce it or not after see the usage.

Miguel made a multifunctional jacket which can be made wider, the sleeves hang from the neck, you can use it as a scarf, when you bring it in front; you can use it as a pocket or glove, when you bring both of them back behind and combine them, you can use it as a back pack (Picture:42). The zipper enables to make the jacket have many functions. The idea itself is wonderful but the remade designer said it is takes too much work and costs are too high. They said the jacket would instantly sell out like Cheap Monday or other designer stores but it is hard to produce in City Mission.

The hardest part of the project was the poor communication between both of the design students. The project was running behind schedule even though I requested that the students to sent their profile by the specific date. At first, one of them sent the profile documents two weeks late and the other didn't send it at all. I had to make the profile on behalf of the student. Then, they sent made up garments and patterns to City Mission about three weeks late. 

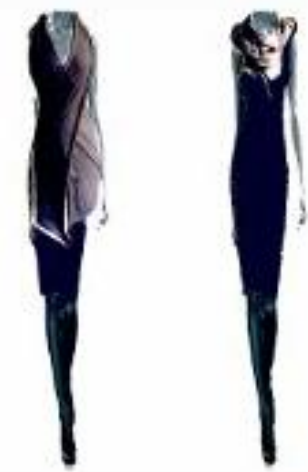

Picture: 41 Evely Lebis
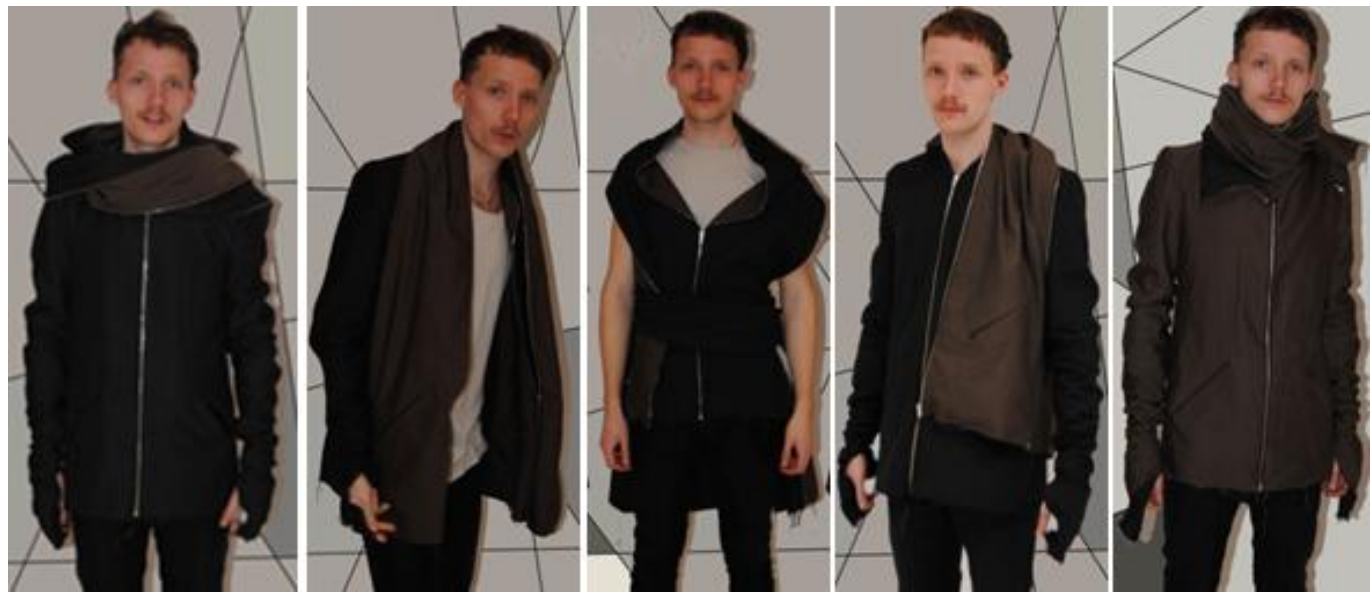

Picture: 42 Miguel Lucas

\subsubsection{Result and Analysis}

The result was we couldn't produce any of them. There are several reasons why we couldn't produce and several points for making the project happen in near future.

The biggest problem of proceeding with the project was bad communication, between Stockholm and Borås. The designer should be good at communicating over emails. I sent very informative emails, I stated clear dates for every steps. I also called. My requests were not kept after all. For the next project, we need to have some students who are better at communication, especially if for the school of the students is not in 
Stockholm. Miguel suggested me he could make another garment for City Mission. Unfortunately it was too late for this to happen this time. If we had good communication it could have been possible.

The second reason was that although Evelyn and Miguel's designs were fantastic and they can be sold in commercial stores or brand name stores. However, they were not for second-hand stores. Perhaps the designs were just too advanced for second-hand stores at the moment. There were design problems and material problems. We needed to consider about the material City mission get as donation, and we needed to have more information about what kind of customer City Mission has, what customer of City Mission wants. One of remade designer told me several years ago fashion design students from other school, made scarf with jersey which you can use many ways. The hem wasn't sewn. The customer thinks it is a bad finish. Also the customers will have trouble how to use them because so many ways to use the scarf. Multi style is not the same as multifunctional. I found that Evelyn's design is not multifunctional but multi style.

Evelyn's designs are only for jersey material and hems aren't sewn either. The pants are not stitched on the waistline; I don't know how they hold on to the body (Picture: 43). But the customer in City Mission doesn't buy trouser as much as other garments according to the store manager. They have to try them on before purchase which makes them less likely to buy the pants. Mrs.Marie Teike said they didn't want to produce trousers. The dress was beautiful but the size is for tall and very thin people. It is made with jersey so it will fit to everyone but all of bodylines are shown (Picture: 44). Scarf 1 has complicated structure (Picture: 45), Scarf 2 doesn't have complicated structure but both of them need to have instruction on how to use (Picture: 46), which wastes the workers time. Evelyn's patterns are not usable for cotton or other materials, only for Jersey. Jersey is flexible, stretchable material; you don't need to think about human body movement when you create a pattern. But for cotton or other non-stretchable material, we needed to have another pattern. 
Miguel's designs are used many zippers. It has long 6 zippers and small 6 zippers. It is hard to get a long zipper from donations; they need to buy them and it costs $10 \mathrm{kr}$ for each. It is complicated structure; need a lot of work and takes a long time to produce. According to Ms.Pernilla Rozenberg, it takes a month to produce in total. The cost will be $1000 \mathrm{kr}$ at least. Customers of City Mission wouldn't buy 1000kr clothes and City Mission would not be able to produce this.

Multifunctional concept was very good but I figured that this idea should be easy to use at the same time.
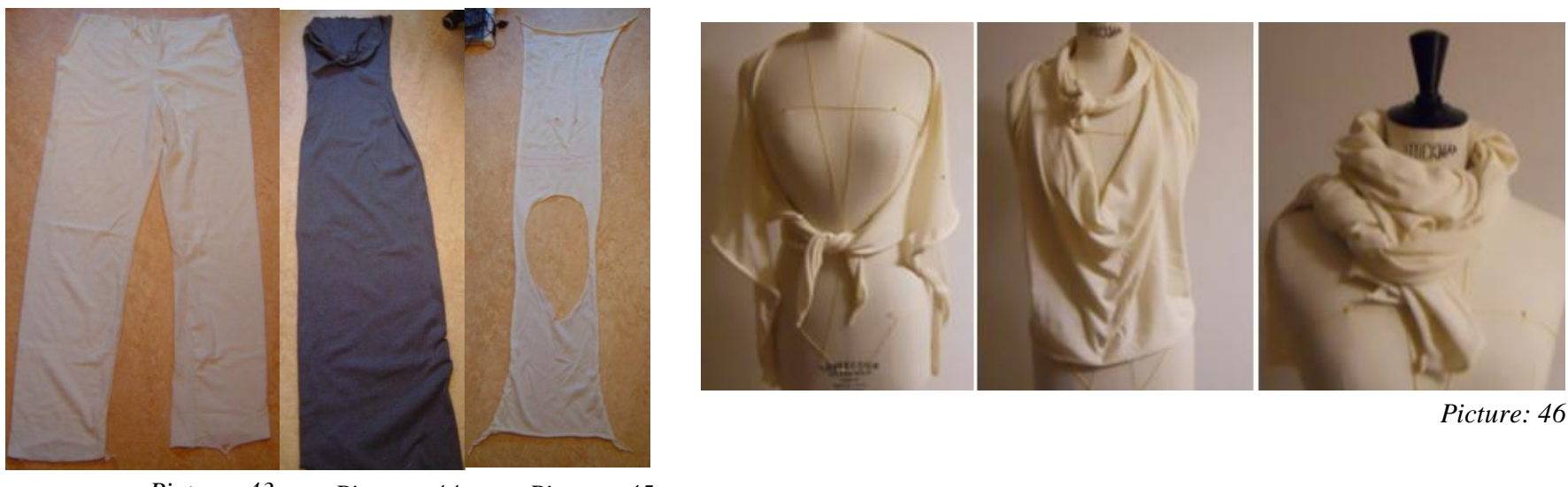

Picture: 43

Picture: 44

Picture: 45

\subsubsection{Improvement points}

I suggested to City Mission to continue the project with another school in Stockholm so that the students can come to the stores themselves, checking the materials and analyzing the customers before starting the design process. Direct communication between students and City Mission remade designers are needed. The patterns should be used for many materials, and hems should be sawn. If it is multifunctional or multi style it should be easy to use, and sold with clear instructions. The school can give lecture students the opportunity to make garments under circumstances, such as material limitation. Students can learn consumer insight as well. It 
is a great chance for City Mission to also find a new way for sustainability in fashion with the students. The customers of City Mission are not keen on complicated, multifunctional fashionable clothes for now. Despite this, I still believe we can sell multi style fashion garments if we made a user friendly document, showing clearly with pictures how the use the garment correctly. However, it is very certain that we need to put in more effort when we sell multi style garment.

Advertisement for the project is essential to let public know that we're making attractive garments out of second-hand material. If we continue the project with students, I believe we can gain a variety of customers. At the same time it can be expected to change what customer wants from City Mission. City Mission might be able to sell 1000kr remade garments in the future.

\subsection{PROJECT 3: Sell remade products to Japan}

\subsubsection{Project Concept}

One idea of sustainability in fashion is "working globally and help each other". I would like to introduce what Stockholm's City Mission does in the community to Japan. Ideally I would like Japanese designer and remade skills to be used in City Mission's second-hand in the future.

The second-hand market is very big in Japan but the big difference in Japan to Sweden is that, second-hands in Sweden are selling garments donated by citizens. Most of the items are H\&M or Lindex etc and run by NPO. The money made will be used to help people. On the contrary second-hand stores in Japan are not run by NPO, a commercial enterprise. I wanted to sell my old clothes to second-hand store in Tokyo and I went to the store asked I could sell them. They told me they never buy clothes at the store. There are several second-hand stores buy second-hand clothes from citizens but they only buy famous expensive brand name clothes in a 
very good condition garment (16). Common brands such as $H \& M$ and UNIQLO cannot be seen in second-hand stores in Japan. Some companies buy inexpensive second-hand clothes from citizens in Japan and exported to third world countries, South East Asia and Middle East (17). Most of Japanese people give garments they don't wear anymore to the recycling company which collects old paper and can sometimes end up as garbage. The second-hand stores in Japan buy second-hand clothes from western countries, for instance Sweden; buyers from Japan come to City Mission's Skånegatan store and buy most of garments, but only in Skånegatan store because Skånegatan store is selling fashionable vintage clothes. Japanese people considered second-hand clothes as more "Fashion" than ecological. According to the survey done by British, $40 \%$ of Japanese people have bought second-hand clothes before and the reason was the second-hand garment was good quality and good price. (18). The second-hand market has already been accepted by the majority in Japan. People Tree started in Japan as well so it wouldn't be hard to get Japanese people's attention to NPO based second-hand, if it's a good design and good quality.

Recently H\&M has opened stores in Tokyo, IKEA succeeded to launch in Japan again. Japanese people have since paid more attention to Sweden. According to the worker at Gamla Stan store, Japanese tourists have increased around these three years. They like Swedish 50s and 60s design textile and dish wear. They buy many remade small purses as well. Stockholm's City Mission was picked up in an article as a "furniture store" which wasn't quite correct, in a French magazine Japanese edition called "FIGARO Japon" four years ago.

As for remade products, Japan is more advanced than Sweden, although remade by a commercial enterprise. For example store called HANJIRO's assortments are half remade and the other half is second-hand. They remade jeans, skirts, T-shirts, shirts and bags. These items are resold

\footnotetext{
${ }^{16}$ http://www.ragtag.jp/

${ }^{17}$ http://ichihashi.seikatsusha.net/back/item/all/1264554748.html (Japanese)

${ }^{18}$ http://whatjapanthinks.com/2007/11/27/second-hand-clothes-market-in-japan/
} 
again over internet auction. Here is something City Mission can learn from Japan, regarding their remade section, to be more specific, City Mission can start making bags and jeans.

\subsubsection{Method}

Take contact to well known fashion companies, multi-brand stores in Japan, Japanese like "brand names", as you may know so many Japanese visit Louis Vuitton store in Paris. If I can sell City Mission's products to the companies, Japanese people will easily pay more attention to the products.

I will promote selling remade small purses, cushion covers and shopping bags. Small purses and cushion covers are accepted by Japanese tourist already but I doubt that I can sell shopping bags to Japan. Japanese people care very much about quality. Before I started the project I asked some friends in Japan they want to buy City Mission's remade products or not. They said they would like to buy them if it's not too expensive except the shopping bag. City Mission wants to sell Claesson Koivisto Rune shopping bags to Japan mainly. They have 300 stocks. However, the shopping bag's finish is very poor; edges aren't stitched, thus, thread comes out from the textile. It's sold for $50 \mathrm{kr}$ in Sweden. It would be double that price in Japan; adding on the shipping cost and commission fee. The poor finish is one of the concepts of the shopping bag to consider. The shopping bag is easy and takes shorter time to make. Use it in everyday life and if it's worn out, buy another one. I need to explain the idea very well to companies in Japan.

Since City Mission's second-hand products are one of a kind; it's made with limited second-hand or donated new material. I will send photos of the products to the companies. Then the company will tell us which products they want and we will send them to Japan.

FREITAG sends many products to stores (Franchise stores), they sometimes send unattractive designs or unpolished products. In that case 
FREITAG can take them back, free of shipment. But City Mission can't afford for shipment to take back the product. The best solution is, make the products for Japanese market first, take good pictures then sell them.

As for the shopping bag, City Mission wants to sell as many as possible, it requires a lot of work to take pictures of every products. Also sometimes it can be seen bad fabric design combination with front and back shopping bags. It happens because the worker at the factory can pick freely the fabric for front and back. To avoid the problem, I picked up the textile which the Japanese would like and send the textile to the factory. I put colorful textile in one box (Box: A), and the other box I put plain color textile (Box: $B)$. Then ask the person in charge to give instruction to the workers at the factory to make sure to combine the textiles from Box A and Box B.

As for the cushion covers should be in the size in the cushion sold in Japan. The most common size is $45 \times 45$. City Mission is selling the cushion cover with cushion in Sweden. To minimize the shipment cost, it is the best to sell only cushion cover alone to Japan.

I set a target group in Japan, to make it easier to write description for the products and for the future advertisement. (Chart: 11).

Chart: 11
$\checkmark$ Women
$\checkmark \overline{20 \text { s to } 60 \mathrm{~s}}$
$\checkmark$ Intersted in one of a kind products
$\checkmark$ Intersted in Scandinavian design
$\checkmark \underline{\text { Intersted in ecologically and ethically right products }}$ 


\subsubsection{Process}

Stockholm's City Mission is unknown in Japan. I have to explain what City Mission has contributed to the society and how big they are in Sweden first. I asked supervisor if there are any documents explaining City Mission. Then I could get one document describing that they have been working for homeless, vulnerable young people etc. I translated into Japanese and got a review from a friend of mine in Japan who works in fashion industry. She said it is too heavy issue for Japanese, emphasizing too much on the "homeless and shelter". It would be better to explain and emphasize more on the "Fashionable products and famous organization contributes to the society". Of course there's no documentation as such. I needed to create this myself. I found the City Mission's logo is written in special font, I needed to have help from a person in charge of PR to make it a more professional finish. But the supervisor (Mrs.Janna Hellerup) was too busy to get me the help; I needed to do on my own. First I made a document which describes Stockholm's City Mission's second-hand and remade (Appendix 1). For second-hand part, I included information that the second-hand is supported by Stockholm's citizen's donations and 75\% of sales are used for the shelter for homeless and helping people. For remade part, I described that City Mission's remade has been recently launched, but they have already collaborated with a well-known designer, and Japanese tourists often buy City Mission's products. Secondly I made a document describing the shopping bag. The shopping bag is hard to sell because of the finish; it needs to have a documentation explaining about its ecological values and that it is made by famous designer (Appendix 2). I made the documents in Japanese and in English to make it more look like an international organization. Thirdly I made documents about the stores. I included many pictures of the stores to show how fashionable stores they have (Appendix 3-6).

I picked up textiles Japanese might like for the products. Remade designer made especially for Japan, five small purses, four cushion covers and seven shopping bags (Picture: 47,48 , and 49) 

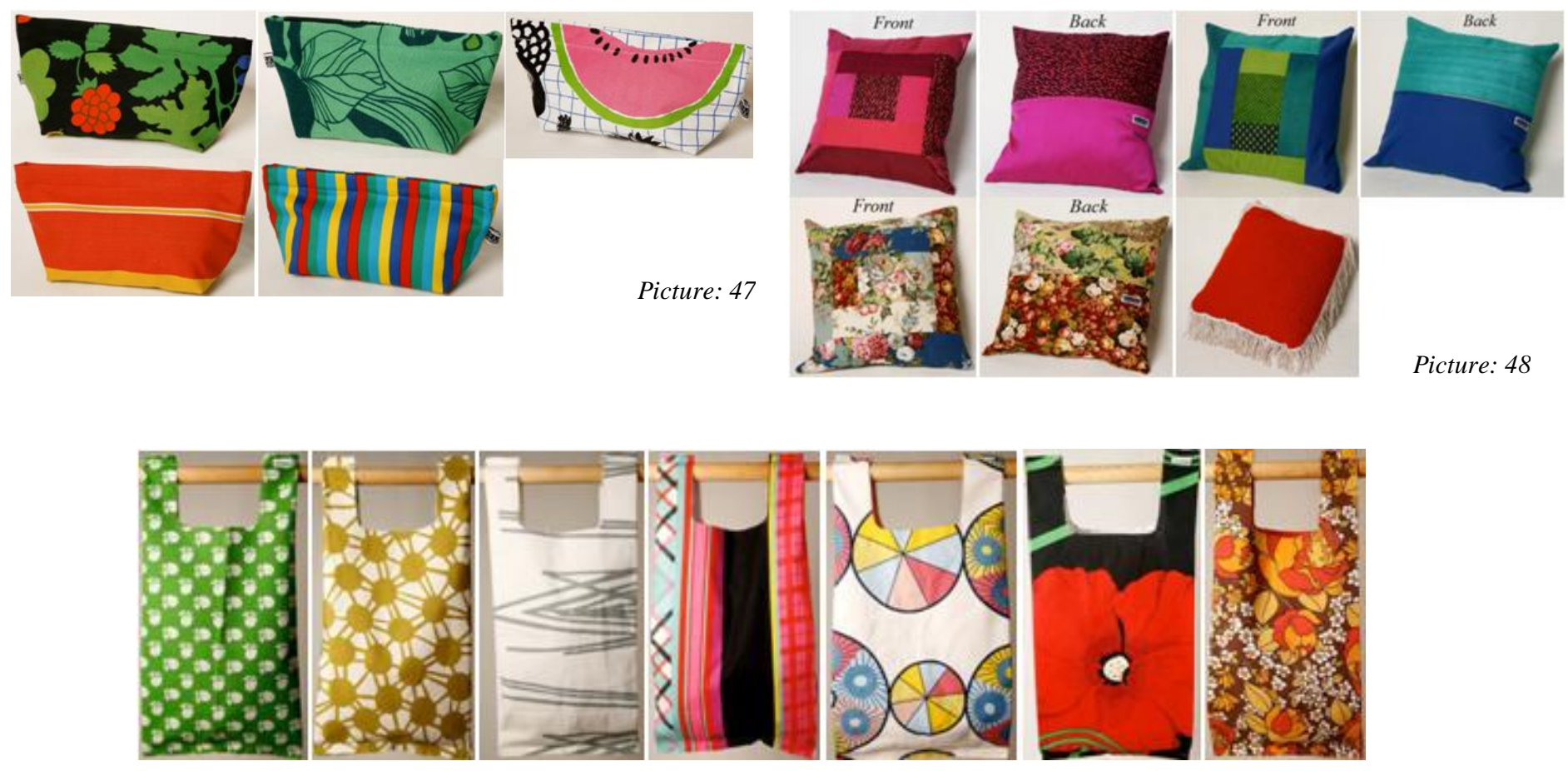

Picture: 49

For the photos of the products, I asked a semi-professional photographer who is working for City Mission, Ms. Erika Rougeux. I printed them in a color printer in the office to cut the cost to print the photos. Additionally, I describe my other projects to show that City Mission is actively engaged in sustainability and willing to take a new challenge and new ideas. Also I asked supervisor in City Mission that I would like to have "@Stadsmissionen.se" mail account. I assumed communication between the companies in Japan would be over email. "@Stadsmissionen.se" looks more serious than “@hotmail.com”. 


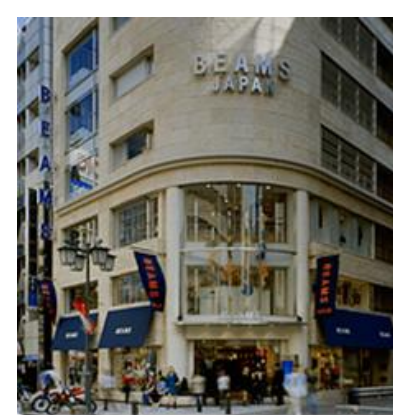

I chose companies to try to sell in Japan. The companies must have the customer same as the target group, as I believe City Mission's remade products will have. If I can get a contract from the company, Japanese people will pay attention to City Mission easily. I chose "BEAMS" (19) (Picture: 50) and "UNITED ARROWS GREEN LABEL RELAXING" (20) (Picture: 51) which are multi-brand stores similar to BARNEYS NEW YORK (21). They are selling brand name clothes from in and outside of Japan. Their price range is, for example around $700 \mathrm{kr}$ to $2000 \mathrm{kr}$ for women's dress. One of BEAMS stores is selling furniture and home Picture: 50 textile from Scandinavia and might be interested in City Mission's remade products. UNITED ARROWS GREEN LABEL RELAXING has some ecological activities, such as reducing shopping bags. They had a campaign for customers to bring their old clothes purchased in the stores and receive a coupon. The customer can use it when they buy new clothes in their stores. They also have 10 Swedish designers' Picture: 51 products in their assortments.

Therefore I assumed they might be interested in City Mission remade products and activity. One thing I'm concerned about is that they haven't sold second-hand clothes or second-hand remade before; they only sell good quality products. City Mission's second-hand remade products are not high quality compared to these brands; especially shopping bags poorly finished are hard to sell in Japan.

Another option to sell to Japan is through internet stores. Fortunately, I have an acquaintance who works in the Swedish embassy in Tokyo, who introduced me to a company called "Living Swedish" (Picture: 52) (22). The internet shop sells Swedish products to Japan. The owner of the company

\footnotetext{
${ }^{19}$ http://www.beams.co.jp/

${ }^{20}$ http://www.green-label-relaxing.jp/

${ }^{21}$ http://www.barneys.com/

22 http://fswl.shop-pro.jp/
} 
of Living Swedish is called Scandinavian Wave AB (23), located in Stockholm.

They have an office in Tokyo. They decided which products to sell to Japan in the Stockholm office. The company always participates in a Swedish fashion cultural event in Tokyo called "Swedish Style". If we're lucky, City Mission can get into the event and let Japanese people know about City Mission's activity.

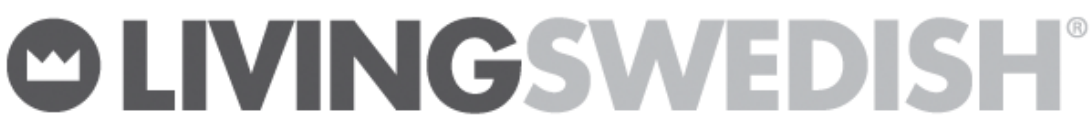

Royal Scandinavian Design Store・スウェーデン発、北欧デザイナーズ雑貨

Picture: 52

\footnotetext{
${ }^{23} \mathrm{http}: / /$ www.scandinavianwave.jp/sv/
} 


\subsubsection{Result and Analysis}

Although I sent documents to BEAMS in early April and to UNITED ARROWS GREEN LABEL RELAXING in the end of April I haven't heard from them yet. I assumed that City Mission's concept and their concept didn't meet. City Mission's main concept is helping people and reuse material. The companies in Japan focus more fashion and good quality. Luckily I received reply from the internet store; Living Swedish. The meeting was held on May $17^{\text {th }}, 2010$. I brought all of products that can be sold in Japan. The person in charge (Ms.Okazaki Junko) explained the system for business.

The system is very simple and low risk for them. They won't buy products from the production companies. If the product is sold, the production company will get the money. They offer the place in the internet shop for free. They will add their commission fee (includes, taking photo of the products, writing description of the products, wrapping for shipment and shipment cost), it will be higher price than the price City Mission sells in the stores.

As for negotiation of price, I told Ms.Okazaki Junko, the person in charge of Living Swedish, City Mission wanted to get the same earnings as in their stores. City Mission sells cushion covers for 250kr; they want to get 250kr through Living Swedish. The person in charge said it is hard to set the initial price in Living Swedish as the same as selling price in City Mission's stores. In the end the person in charge gave me alternative. If I write description of the products in Japanese for free and give them products' photos and other needed photos to explain about City Mission, they will consider taking the price as the same as the selling price in City Mission's stores. The negotiation about the initial price in Living Swedish will be held early of June 2010.

Ms.Okazaki Junko asked about the release date in Living Swedish website. City Mission is planning to open a store in Åhléns in August 2010. Ms. Okazaki Junko suggested that it could be a good advertisement for Åhléns opening if we set the release date in Living Swedish in August. Also it is 
nice to release before August to get attention from Japanese people before the opening. Japanese tourist might come to Sweden for summer vacation. The release date will also be discussed in middle of June.

In the meeting, we talked how much City Mission can sell in Living Swedish. City Mission has several projects including Åhléns store opening at the moment. City Mission can take care of this Japan project after August. Thus it is better to start slowly. We already have products to Japan, five small purses, four cushion covers and seven shopping bags. City Mission can sell the products until August. Living Swedish agreed to start slowly for now then expand in the future.

Living Swedish is interested in selling the small purse and cushion cover. However, they are not interested in selling the shopping bag. The poor finish was the problem. The person in charge suggested that fabrics are beautiful, so that they might be able to sell with other products such as the small purse, and give the shopping bag as a gift. For example, small purse costs 200kr. Shopping bag cost 50kr. Living Swedish sell purse with 250kr and give one shopping bag then the sales is the same as selling the purse and shopping bag. This could be a good alternative.

Another option they gave me was to bring the shopping bag to the event, which Living Swedish will have in Tokyo in fall 2010. Consumers in Japan can see the shopping bag in the even introducing City Mission's activity. It might help to sell the shopping bag in Japan. During the meeting, they will try to bring the shopping bag to the event then we can see the reaction from the consumer in Japan. After that Living Swedish can decide if we will sell it as gift or not.

Living Swedish wasn't interested in shopping bag but the T-shirt collaborated with young designers. There are some T-shirt City Mission couldn't sell. This is a good opportunity to sell all of them. Also it is good for designer's advertisement; Living Swedish will put the link of the designer's website in the store. We will discuss selling T-shirts in middle of June. As small summary, Living Swedish will sell the small purse and cushion cover. 
The reason why it went well with Scandinavian wave is that owner of the company is Swedish (Mr.Martin Koos), the head quarter is in Stockholm, and they have much better understanding about City Mission. Also most of workers in Living Swedish are Swedish and Japanese. They know Japanese market.

In the end the business style of Living Swedish was a match for City Mission's situation at the moment. City Mission can sell what they have now thus no need to be rushed.

\subsubsection{Improvement points}

One improvement point is City Mission is better to try working on improving quality of the products. It leads not only to getting more customers but also it is ecologically good to make a good quality product. The product will last long and the customer doesn't need to throw it away. The second point is City Mission can have more assortments in remade section line in the future.

The third point is that City Mission can spread the market to sell. This time I picked Japanese market; in the future City Mission can try North America or other European countries. The customers in these countries are less picky than in Japan. In North America, there's famous second-hand store called Thrift store run by Salvation Army. They haven't tried remade yet in Canada. One of the reasons City Mission couldn't make so many products is due to the shortage of work force. At the moment they are trying to reconstruct production line in remade section, after the production line system works regularly, we can look to the next challenge. 


\section{CONCLUSION}

I initiated this project in order to get attention from people, especially those who weren't previously interested in second-hand products. In order to make these ideals come true we need to get a new "Fashionable" image for second-hand such as People Tree. City Mission can't be on the same stage as H\&M or Gina tricot who provide "Fashion for everyone". The City Mission remade section needs to add additional values, like "Ecological", "Ethical", and "Help the community". Fashion is linked to consumption nowadays. City Mission can show the other way of enjoying fashion to the public (24).

I conclude my research in the points below.

- We need to express that City Mission is adding values such as ecological friendliness, and helping the local community through remade products.

- The role of design in sustainability within the fashion industry is huge, but designers need to have consumer insight.

- We need to attract new customers in order to let people know about sustainability.

- It takes time to let people know about sustainable fashion.

Stockholm's City Mission is the first non-profit organization to start a remade section in Sweden, but it's not yet well-known. We were lucky to get an interview in METRO about the T-shirt project, but we need to advertise more about remade. Because the remade section's sales haven't increased so well it means City Mission hasn't quite succeeded in getting new customers.

I learnt from the project where I collaborated with fashion design students in The Swedish School of Textile that, it is too early for City Mission to apply the designs which are accepted in other commercial stores such as Miguel

${ }^{24}$ Fletcher, K.(2008), Sustainable Fashion \& Textile Design Journeys, London; Sustainable Fashion and Textiles, p126 
and Evelyn's. Second-hand remade isn't yet known in the public, and customers are not expecting commercial taste when they visit City Mission. They expect cheaper second-hand clothes. It takes time to let the public know about the concept of "remade". For example, fair trade's sales - was

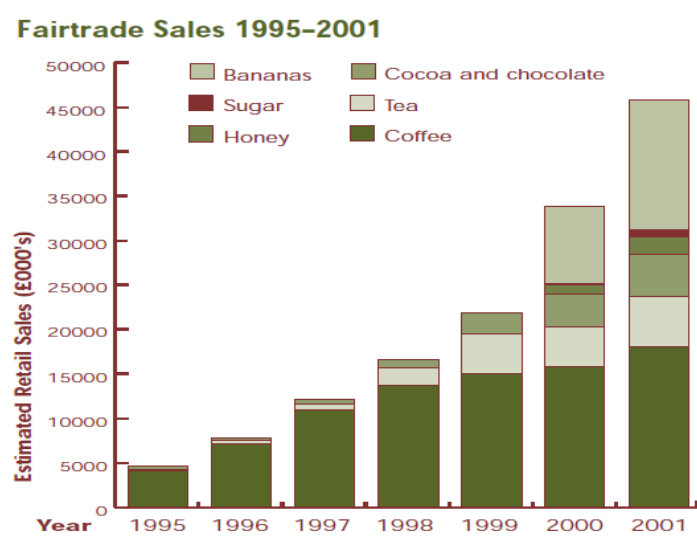

Chart: 12 very small in 1995 compared to 2001 . In 2000, you could see a lot of converge of fair trade in the media. This leads to larger sales (Chart: 12) (25). It needs some time if City Mission keeps improving its design, and good reputation about remade garments, sales will improve. Spreading out a good reputation through people is the big advertisement City Mission can expect for future.

Initially, I think it is better to start by excelling at producing second-hand remade home textiles. Home textiles are more disposables, such as wipes for tables, easy to produce as well. Then remade will be standard in second-hand.

I got a lot of attention through the T-shirt the project - thanks to the power of collaboration with a designer. Through this project, I learned that helping one another through collaboration and design are effective strategies for sustainability in fashion. Through the projects I worked on, I had a lot of contact with people I didn't know, and got a chance to know them and work with them side-by-side. Projects like this one keep people connected. Sustainability in fashion positively affects human connections as well.

We can't get people's attention for sustainable fashion over night; we need to keep trying new strategies all the time. Although ecological fashion is a new field in the fashion industry, it has a lot of potential, and, I look forward to trying new strategies in the future.

\footnotetext{
${ }^{25} \mathrm{http}: / /$ www.fairtrade.org.uk/includes/documents/cm_docs/2008/a/annreview1.pdf
} 


\section{FUTURE PROPOSAL}

The future proposal I would like to submit to City Mission is that we try to keep focus on the "Originality or advantage of City Mission" for secondhand remake section. My propositions to City Mission are as follows.

- Collaborate with fashion design schools and make garments together.

- Sell DIY KIT to remake garments or home textiles.

As I mentioned earlier, (6.2.5 Improvement points, P.40) City Mission can provide good education to fashion design students. I will suggest to City Mission to obtain a contract with several fashion design schools and make remade garments together. Sustainability will be a big issue in the future as well, and a school can teach students how to make good garments with limited resource, as well as how important consumer insight and market research are. The class in City Mission will be practical and very effective for the future of students.

City Mission is working locally as, local people donate clothes now. It is better for City Mission to have a stronger relationship with consumers for successful sustainable fashion. It is because sustainable fashion is about

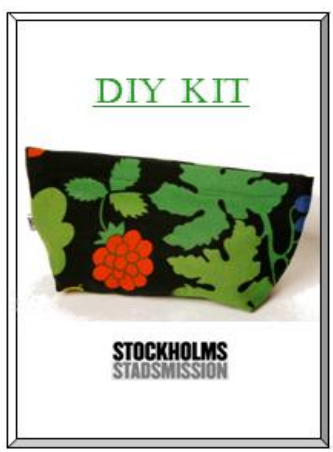

Picture: 53 Future DIY KIT image having a strong relationship between consumers and producers (26). For starters, they can sell "DIY" kit which includes a pattern, final product photo, fabric and other needed materials (Picture: 53). It can be a gift. For those who don't want to make the garment themselves, the finished product is always available in the store. People will have more interest in secondhand clothing, and people can get to know each other through the garment. This DIY KIT idea can be a good beginning for a strong relationship between consumers and producers. If it goes well, for the next step is that local people can sell their remade products in the City Mission store.

Citizens can participate in the production - and I think it would promote harmony in society.

\footnotetext{
${ }^{26}$ Fletcher, K.(2008), Sustainable Fashion \& Textile Design Journeys, London; Sustainable Fashion and Textiles, p125
} 
1: http://www.globalexchange.org/campaigns/sweatshops/3919.html

2: http://www.euromonitor.com/Clothing_And_Footwear_in_Sweden

3: http://www.sweden.se/eng/Home/Society/Sustainability/Facts/

Sustainable-livingGoing-back-to-the-future/

4: http://www.thedesignofprosperity.se/speakers.asp?id=5

5: http://www.ecouterre.com/9045/16-eco-fashion-predictions-for-2010/

6: http://www.stadsmissionen.se/Secondhand/Remake/Tygkassen/

7: http://www.ckr.se/

8: http://www.lånegarderoben.se/

9: http://www.goodlifer.com/2010/03/clothing-libraries-a-shift-from-wastefulto-resourceful/

10: Fletcher, K.(2008), Sustainable Fashion \& Textile Design Journeys, London; Sustainable Fashion and Textiles, p118

11: http://www.thedesignofprosperity.se/speakers.asp?id=5

12: http://www.ecouterre.com/9045/16-eco-fashion-predictions-for-2010/

13: http://tshirtstore.se/

14: http://thedesignofprosperity.se/2009/profiles.asp

15: Fletcher, K.(2008), Sustainable Fashion \& Textile Design Journeys, London; Sustainable Fashion and Textiles, p154

16: http://www.ragtag.jp/

17: http://ichihashi.seikatsusha.net/back/item/all/1264554748.html (Japanese)

18: http://whatjapanthinks.com/2007/11/27/second-hand-clothes-market-injapan/

19: http://www.beams.co.jp/

20: http://www.green-label-relaxing.jp/

21: http://www.barneys.com/

22: http://fswl.shop-pro.jp/

23: http://www.scandinavianwave.jp/sv/ 
24: Fletcher, K. (2008), Sustainable Fashion \& Textile Design Journeys, London; Sustainable Fashion and Textiles, p126

25:http://www.fairtrade.org.uk/includes/documents/cm_docs/2008/a/annrevi ew1.pdf

26: Fletcher, K. (2008), Sustainable Fashion \& Textile Design Journeys, London; Sustainable Fashion and Textiles, p125 


\section{STOCKHOLM'S GITY MISSION'S SEROND HAND REMAKE}

Stockholm's City Mission is a non-profit organization founded in 1853 in Sweden. We have helped from young people to elderly and homeless and vulnerable to get back into society and education. We have received donations from well-known companies such as L'Oréal, Toyota Center, and Burger King.

Stockholm's City Mission's second hand was founded in 1927. We received donations from citizens and companies. Companies donated to us clothes, textiles and others which they can't sell. Currently we have eight Second hand stores in the Stockholm area. Each store has its own concept; the store in Gamla Stan has antiques, while the store in Skånegatan has brand name clothes. You can find your favourite store. In 2009, we opened a store in a shopping mall: a second hand shop. The interior of the shop in the shopping mall is very modern and fashionable, attracting young people and families.

Stockholm's City Mission Remake is our original brand. The brand applies to clothing, home textiles, furniture and more. We receive new textiles which companies can't sell about 16 tons annually. Our remake brand is inspired by new fabric, old fabric and old furniture. We provide environmentally-friendly, well designed products for the good will of society. In 2008, we collaborated with well-known Swedish designer "Claesson Koivisto Rune" and made a shopping bag. The shopping bag is fashionable, user friendly and environmentally-friendly.

Each Stockholm's City Mission's remake product is made by hand. We provide work for city's homeless and vulnerable. Also, all sales are used for the activities of The Stockholm's City Mission.

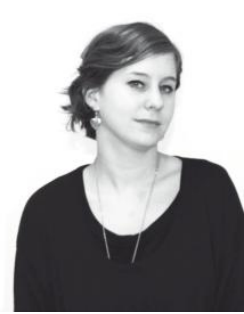

Stockholm's City Mission's REMADE Designer PERNILLA ROZENBERG

She got her textile degree at Glasgow School of Art in Scotland and has since worked within fashion production along side with community projects combining the arts and social work in both Sweden and Scotland. 


\section{STOCKHOLM'S CITY MISSION'S REMADE SHOPPING BAG}

This shipping bag is designed by Claesson Koivisto Rune, a well-known Swedish design group for designs furniture, kitchen ware, bathroom equipments, textile, and jewellery designs. They have designed the Sfera building in Kyoto, the interior of Operakällaren restaurant in Stockholm, as well as designing for Cappellini and Iittala. They exhibited in "Venice Architecture Biennale" in 2004 as the first Swedish architect.

The reason they made the shopping bag is the plastic bags which we get at the supermarket, get thrown away and somehow end up to in the sea, which causes the death seabirds. Using paper bags instead are not a good solution. Paper bags are heavier than plastic bags, thus it takes seven times as much as fuel for transportation to recycle paper bag rather than a plastic one. Claesson Koivisto Rune came up with the idea to make a shopping bag together with Stockholm's City Mission who receives 16 tonnes of textiles from companies that unsuitable for selling.

This bag is made with a front side and back side, with double-folded integrated handles, the same optimal design as a plastic bag. Using the textile instead of plastic, the bag is roomier and sturdy. This bag is a greener alternative to the plastic bag. The shopping bag is made by hand in Stockholm's City Mission. City Mission provides work for homeless people and the city's vulnerable. This shopping bag's production contributes to the society as well.
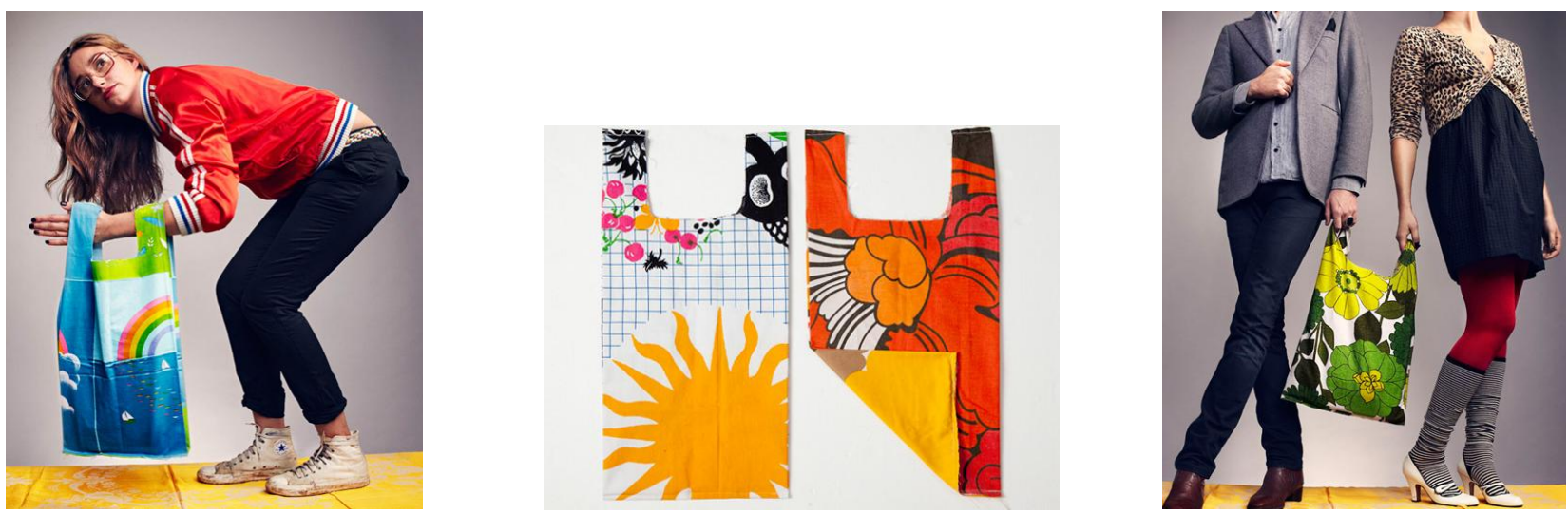


\section{APPENDIX 3}

\section{GAMLA STAN STORE}

Gamla Stan 店は Stortorget 広場にあり、多くの観光客が訪れます。北欧デザインの食器、家具、リメイク商品を中心に取り扱っています。スウエーデンの 1950-60 年代のテキスタイルで作ったリメイクポーチと北欧デザイン食器が日本人観光客に人気です。店内の天井を見ると、建物の歴史がうかがえます。 Gamla Stan 店の隣には Stockholm’s City Mission 本社、City Mission が経営するレストラン、カフェ、ベーカリーの Grillska Huset、教会などがあります。
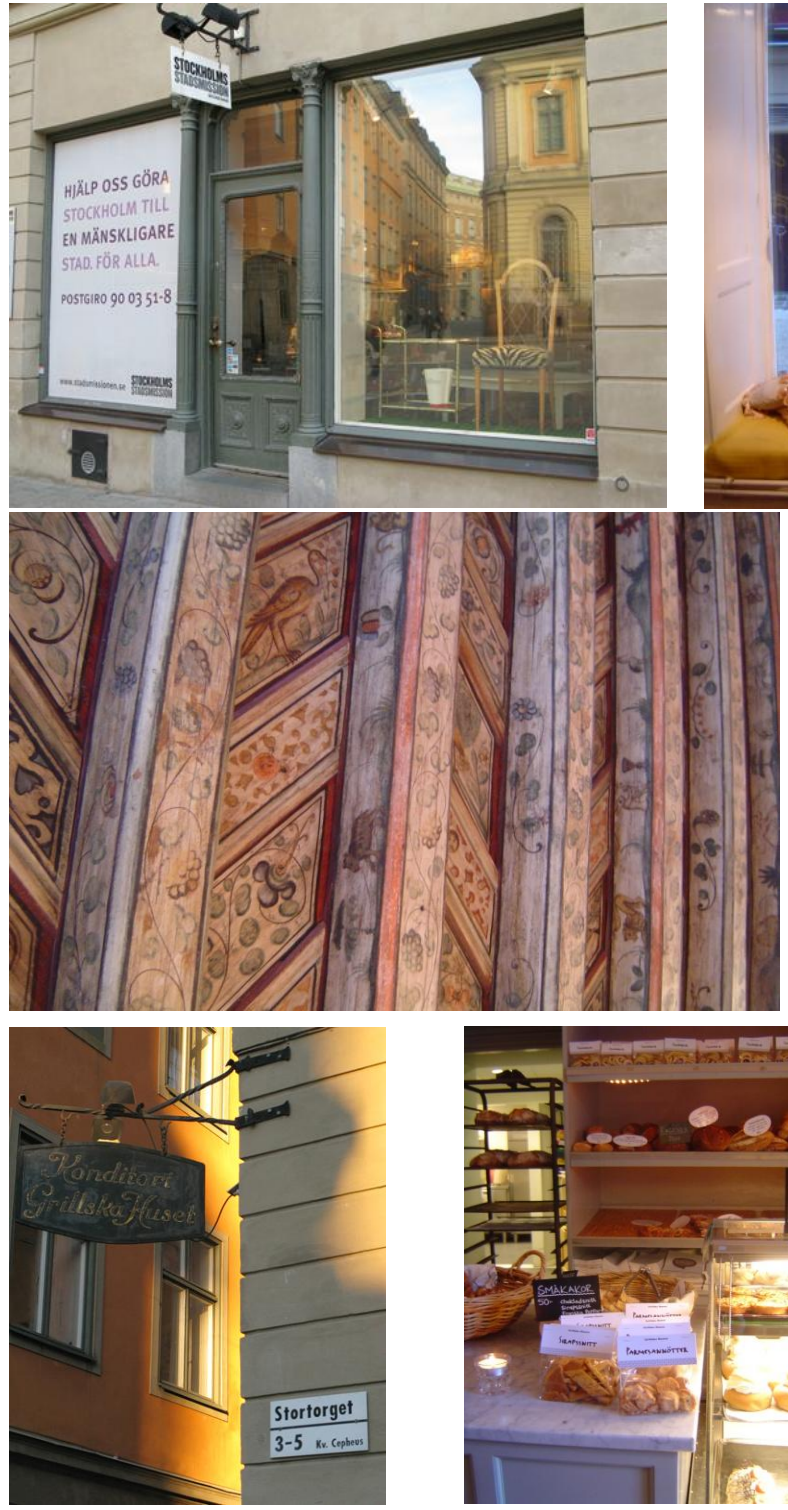
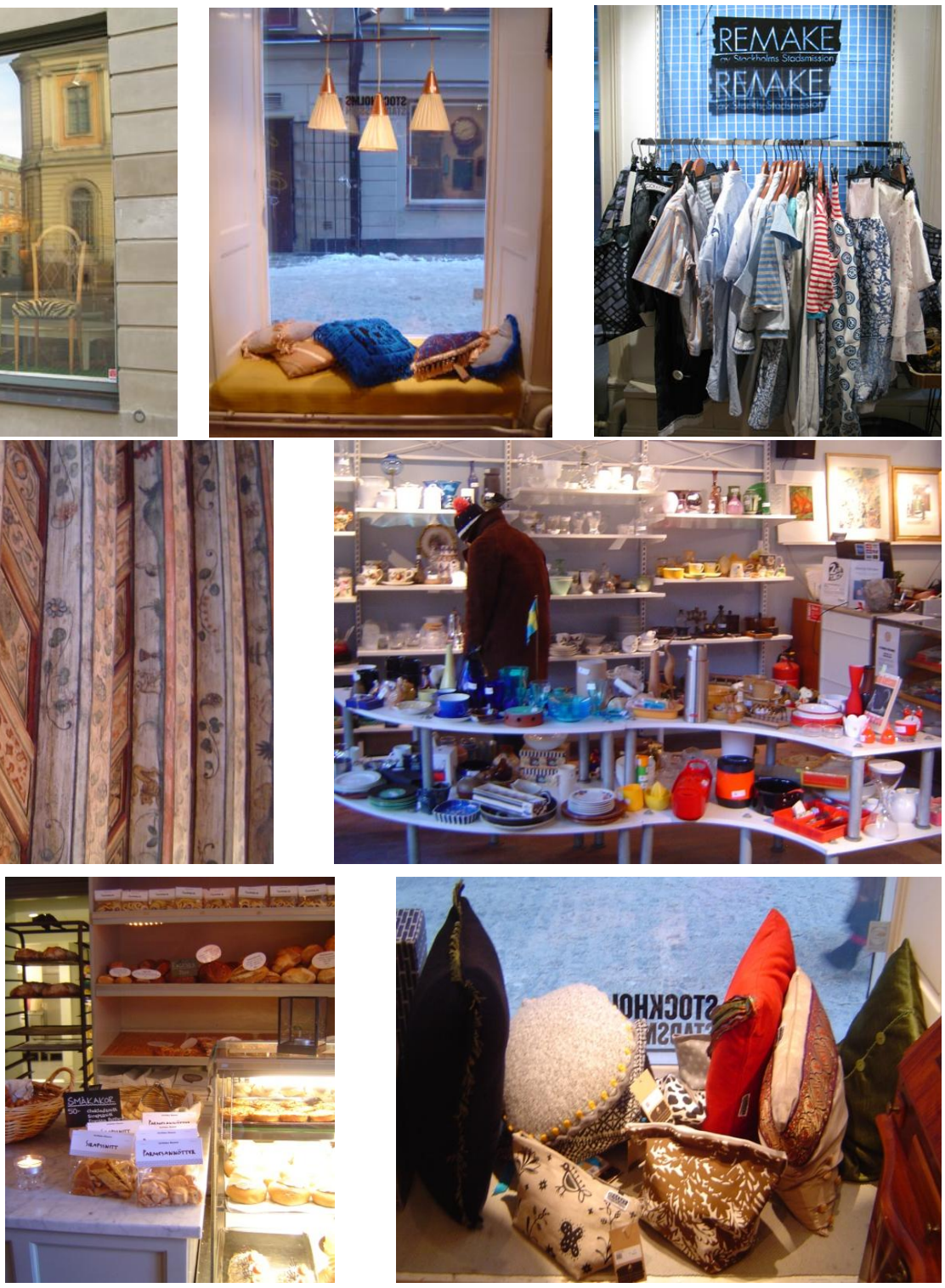


\section{SKÅNEEATAN STORE}

ストックホルムの SOHO と言われるエリアで、オシャレなカフエやデザイナーズショップが立ち並んでいます。 Skånegata 店ではデザイナーズブランドや ヴインテージを取り扱い、北欧デザイン食器、テキスタイルも人気商品の一つです。
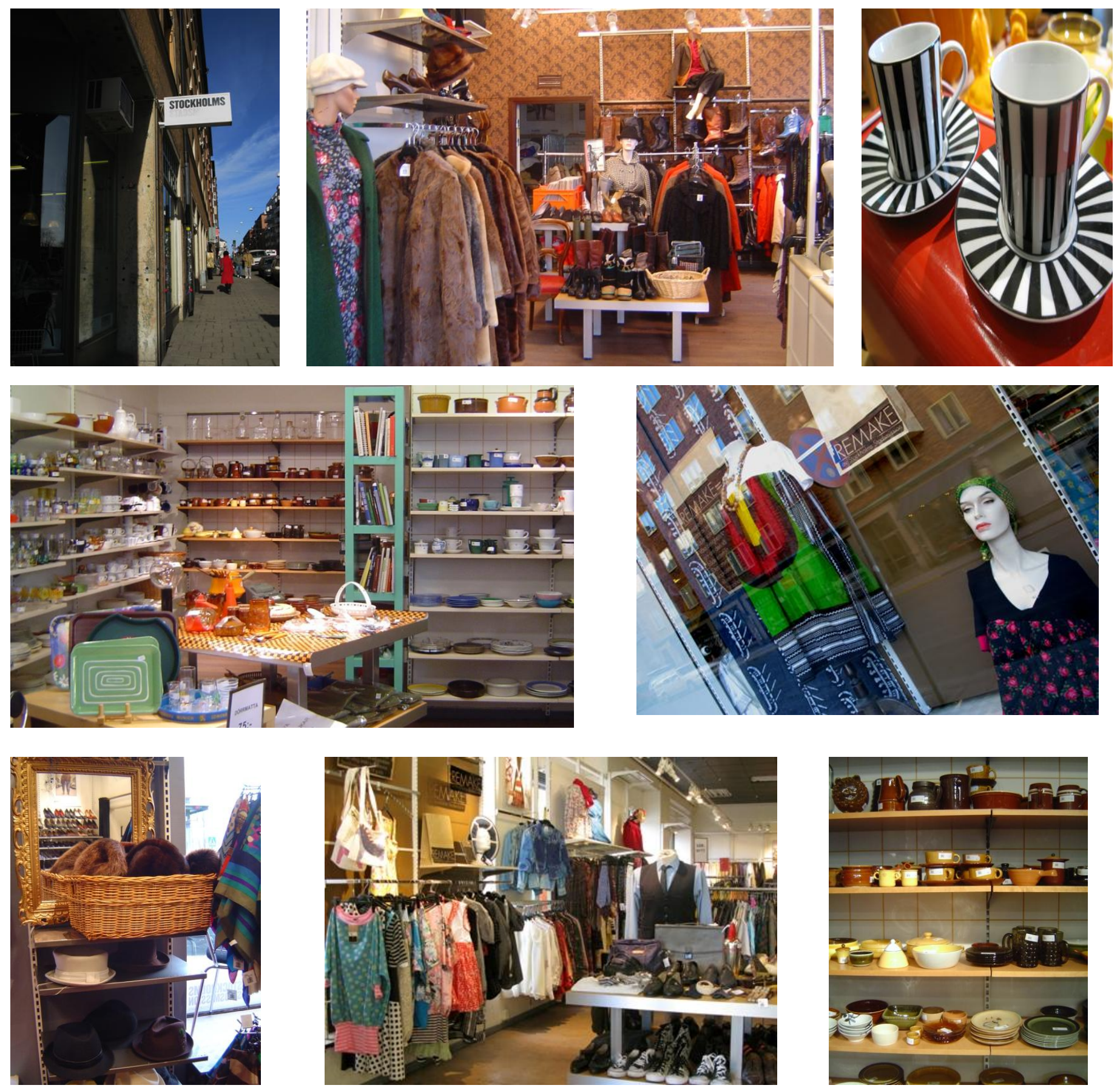


\section{LIUHOLMENSGALLERIAN STORE}

ストックホルム中央駅より地下鉄で 10 分の Liljeholmen の駅前のショッピングモールにセカンドハンドショップ初の出店店舗。リメイク商品、 家具、本、絵画など幅広く取り扱っています。
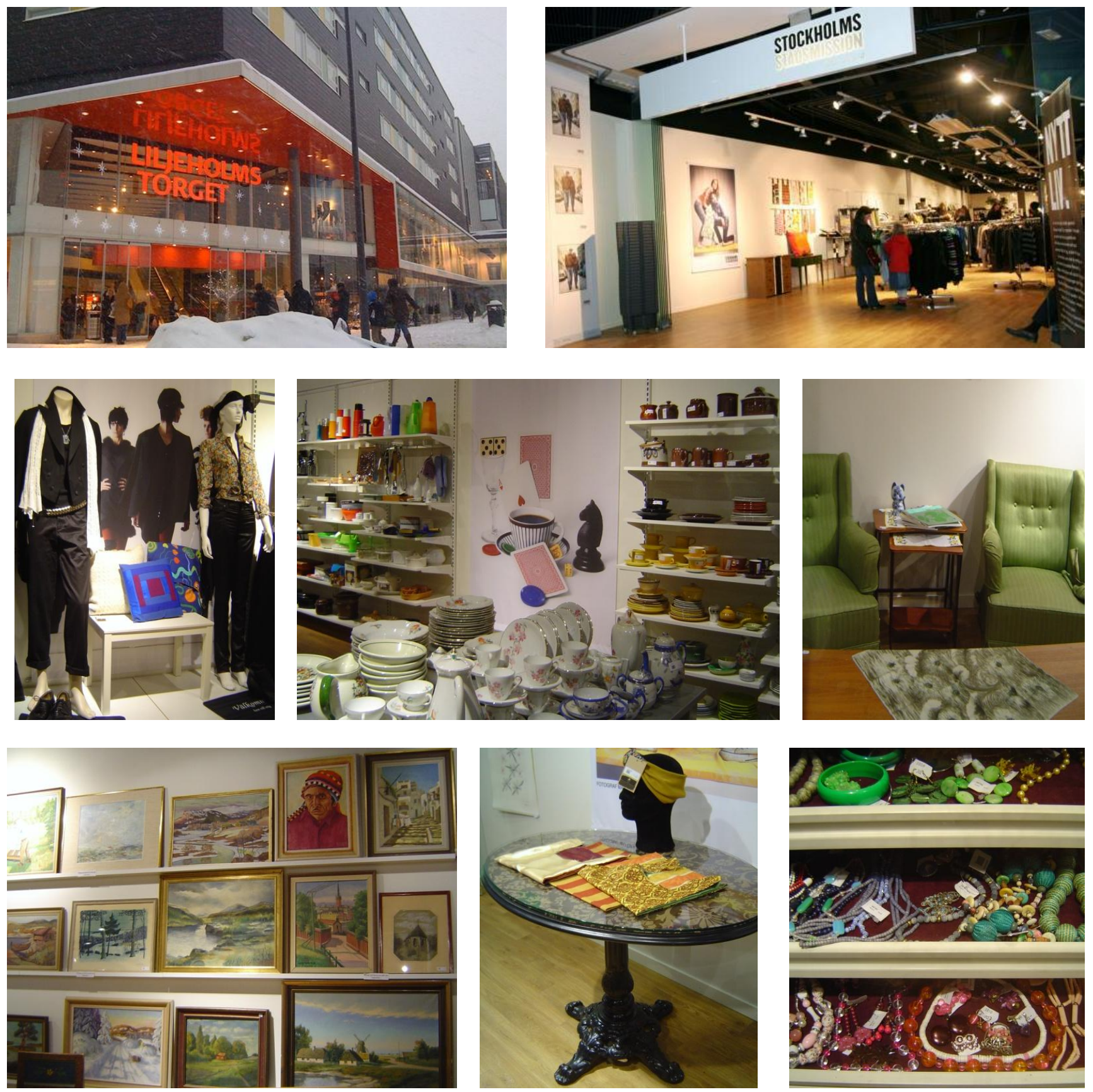


\section{HAGAGATAN STORE}

カフエと DJ ブースのあるユニークな店舗。家具、電化製品、本、楽器など、幅広く、品数が多く取り扱っています。
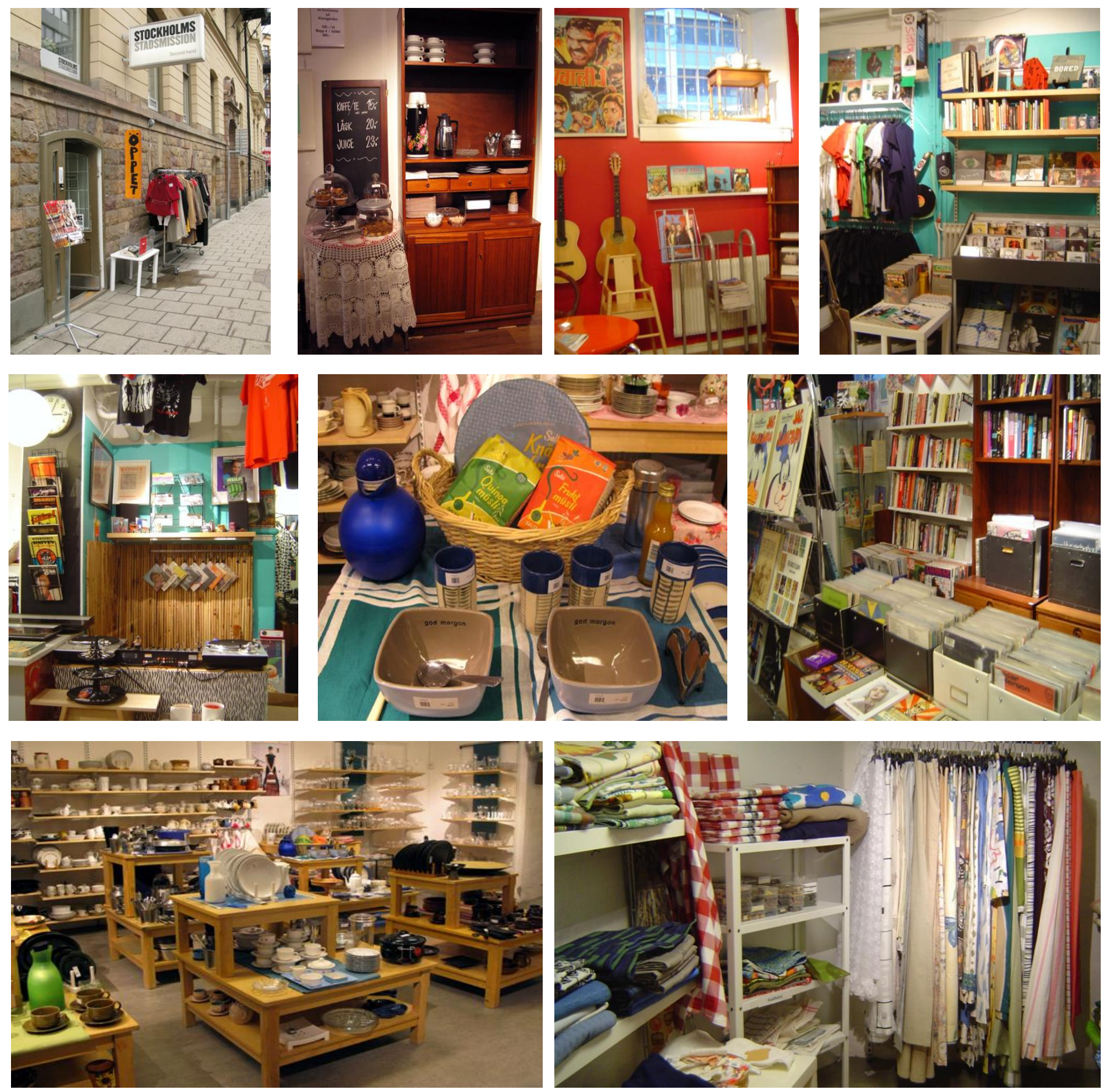